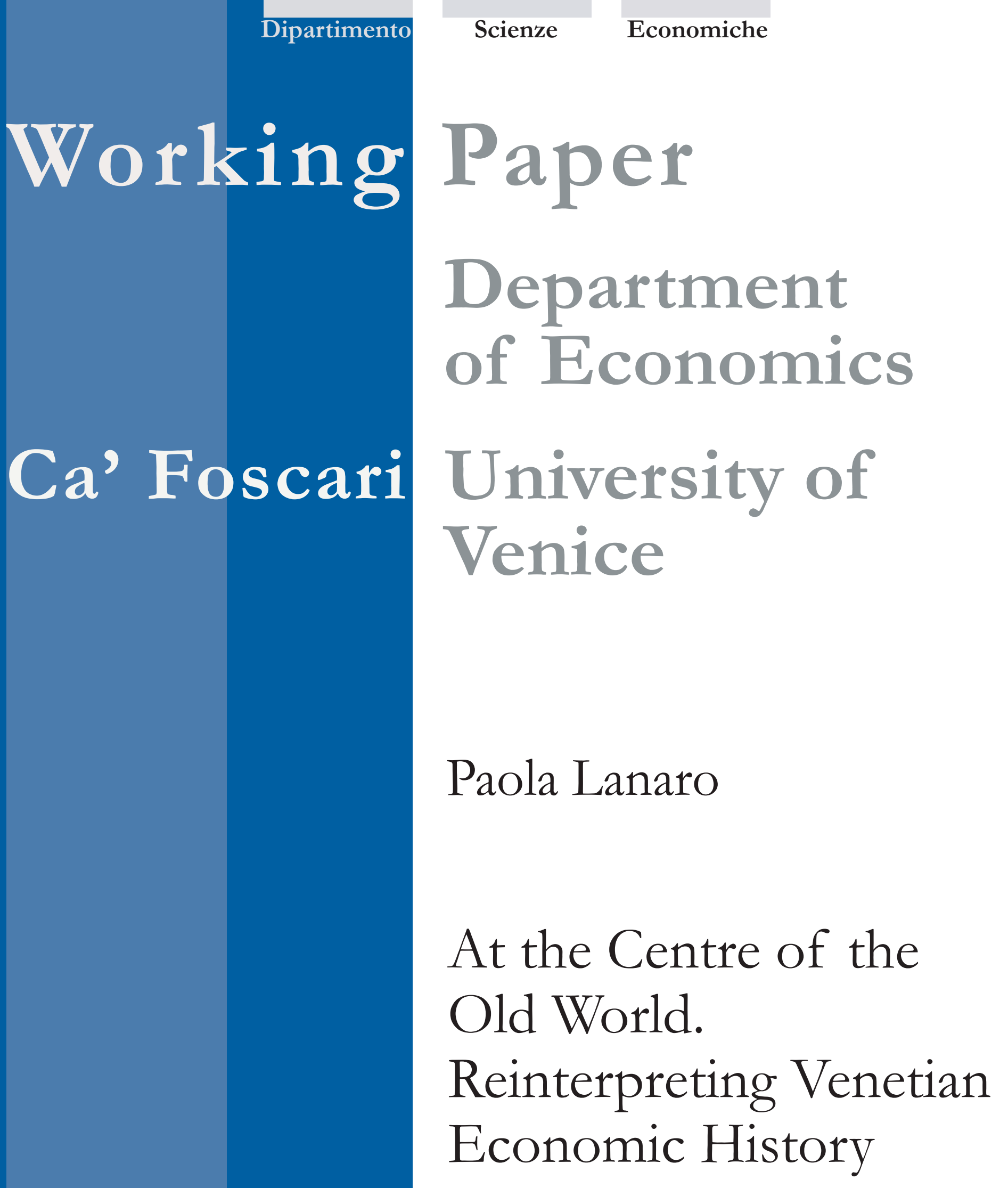




\title{
At the Centre of the Old World. Reinterpreting Venetian Economic History
}

\author{
Paola Lanaro \\ University of Venice
}

\begin{abstract}
This paper aims to provide a general overview on the recent works in the economic history of Venice. Instead of a "pessimistic" interpretation, focused on the lost in the maritime position and on the rigidity of the corporative institution, this paper breaks down on the fundamental changes in the economic framework of the whole Republic of Venice, particularly in its mainland: investment in the agrarian sector, development of new manufactures, foreign market shift from Western to Eastern Europe. Published in the volume: At the Centre of the Old World: Trade and Manufacturing in Venice and the Venetian Mainland (1400-1800), edited by P. Lanaro, Toronto, Centre for Reformation and Renaissance Studies, 2006.
\end{abstract}

\section{Keywords}

Economic history, Venice.

JEL Codes

N63, N93

\author{
Address for correspondence: \\ Paola Lanaro \\ Department of Economics \\ Ca' Foscari University of Venice \\ Cannaregio 873, Fondamenta S.Giobbe \\ 30121 Venezia - Italy \\ Phone: (++39) 0412349154 \\ Fax: (++39) 0412349176 \\ e-mail: lanaro@unive.it
}

This Working Paper is published under the auspices of the Department of Economics of the Ca' Foscari University of Venice. Opinions expressed herein are those of the authors and not those of the Department. The Working Paper series is designed to divulge preliminary or incomplete work, circulated to favour discussion and comments. Citation of this paper should consider its provisional character.

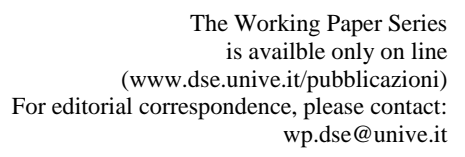




\section{At the Centre of the Old World. Reinterpreting Venetian Economic History}

\section{Economic Historiography on Venice}

During the twentieth century and roughly up to the 1960s, the Italian and international, especially American, historiography on Venice emphasised the maritime vocation of the city and, from an economic point of view, the role la Serenissima played in trading between East and West, between Asia and Europe. Historians who were concerned with economic development became interested in medieval Venetian business men. The biography of Andrea Barbarigo written by Frederic Lane and first published in 1944 in Baltimore (Andrea Barbarigo, Merchant of Venice) is emblematic of the twentieth century's historiographic approach. ${ }^{1}$ Thanks to the number and the variety of documents available-diaries, accounts, ledgers and letters - it was possible to reconstruct the behaviour and personality of Barbarigo, a merchant who was by no means exceptional in the history of the Venetian Republic. This reconstruction enabled Lane to examine in depth Venetian maritime trade and, at the same time, to outline initiatives taken by the government to encourage the activities of merchants; for example the state-organized voyages of the merchant galleys. Lane's work was an attempt to solve some of the problems posed by business history.

It was only from the 1960s on that historiographers' interest in Venice, conceived as an industrial centre, began to take shape in a series of studies. The economic history of Venice written by Gino Luzzatto in the latter part of his life (Storia economica di Venezia dall'XI al XVI secolo) and Domenico Sella's Commerci e industrie a Venezia nel secolo XVII, both published in 1961 and followed shortly afterwards by Bruno Caizzi's Industria e commercio della repubblica veneta nel XVIII secolo investigate more closely the contribution made by the manufacturing sector to the

\footnotetext{
${ }^{1}$ Lane, Andrea Barbarigo, Merchant of Venice.
} 
economy of the city. ${ }^{2}$ While interest in the leading players and in the dynamics of trade in transit in the medieval period diminished, increasing attention was paid in both international and Italian historiography to the diffusion of industries and the role they played in the process of the decline of the city in the early modern age. Even though attention shifted from maritime trade to the industrial sector, the Venetian capital remained the focus of interest. Scholarship at that time analysed predominantly the practices of Venetian land owners, in close connection with the theme of decline. The works of Berengo and Beltrami, ${ }^{3}$ dedicated to agrarian history, were an analysis of peasant society, the typology of land ownership and agrarian contracts, studies that obviously concentrated their attention on the situation on the mainland.

For contemporary economic historians, the chronological sequence from the withdrawal of capital from maritime trade to investment in the primary sector, which was less subject to risk, proves to be too simplistic. ${ }^{4}$

The study of land investment and of a mentality concerned with revenue rather than profit encouraged research into the behaviour and into the thinking of the aristocracy of the subject territories, especially in the crucial period defined as the corsa all'acqua, the period in the sixteenth century and the beginning of the seventeenth when attention was focused on land drainage and the cultivation of rice. It was only from the 1980s that the issue of urban economy and its interstitial link with the economic policy of Venice in relationship to the mainland brought historians' attention to the subject of trade and, consequently, to the complexity of industry in the Veneto and the relationship between the centre and the periphery, that is, between the capital and its subject cities, including those of the so-called Lombard-Veneto region (Brescia, Bergamo, Crema). More than an interest in the subject of the decline of Venice and, in general, of the urban centres in Northern and Central Italy in the crucial phase when world-economy was being established, ${ }^{5}$ recent historical research has tried to highlight the ability of merchants and merchant entrepreneurs from Venice and from the mainland to react to the restructuring of the economy by the hierarchy of Europe. Far from being conditioned by tedious historiographic myths, such as that of the rigidity of the corporative system and of the abandonment of traditional mercantile or industrial activity by the government elite, these studies have brought to light Venetian businessmen's innovative ability to look for new products, new technologies, new professionally organised systems, and new markets. It is in this context that At the Centre of the Old World aims to illustrate the most significant and innovative research in recent years into both Venice and its mainland's commercial and manufacturing activities - studies which disprove old historiographic myths and open new comparative vistas.

\footnotetext{
${ }^{2}$ Luzzatto, Storia economica di Venezia; Sella, Commerci e industrie; Caizzi, Industria e commercio.

${ }^{3}$ Beltrami, Forze di lavoro e proprietà fondiaria; Berengo, L'agricoltura veneta.

${ }^{4}$ Sella, 'L'economia,' 686-688.

${ }^{5}$ Wallerstein, The Modern World-System.
} 
In 1966 Jean-Yves Grenier concluded his work on pre-industrial economy with this statement "l'echange est central dans l'économie d'Ancien Régime, c'est-à-dire qu'il constitue le seul lieu d'observation pertinent pour comprendre l'économie dans sa globalité."6 This introduction shares his views on the pre-eminence of trade in an economy characterized by uncertainty and risk. Our observations will begin with a study of markets and market circuits, and within these, again in total agreement with Grenier, of the material reality of trade, its concrete and repetitive dimension. ${ }^{7}$

2. Regional State and Economic Autonomies: The Example of the Veneto

\section{a. The Heritage of the Thirteenth and Fourteenth Centuries}

During the thirteenth and fourteenth centuries, the presence of many cities in one of the most densely populated regions in Europe was a characteristic feature of the Po Valley, an area bordered to the north by the Alps and to the south by the sea. According to the data collected by Paolo Malanima in a census of cities with more than 15,000 inhabitants in the north and centre of Italy in the fourteenth century, 10\% of the cities in the Po Valley (table 1$)^{8}$ fell into this category. Only in Flanders, Brabant and in Holland could medieval urbanization be compared to that of Northern Italy. ${ }^{9}$

The socio-economic relationship that linked the towns of the Po Valley has been described as a network system: especially the towns in north-eastern Italy, from Mantua to Ferrara and to the cities of the Marca Trevigiana (Treviso, Padua, Vicenza, and Verona, thus almost covering present-day Veneto). Most of them were among the thirty most populated cities of the centre and the north of Italy, Verona and Padua with more than 40,000 inhabitants. ${ }^{10}$ This was defined as "a centralized system of strong cities"11 and juxtaposed with another urban system centred around Venice on account of its large population and considerable economic importance. It

\footnotetext{
${ }^{6}$ Grenier, L'économie d'Ancien Régime, 417.

${ }^{7}$ Grenier, L'économie d'Ancien Régime, 423: “C’est en effet parce que l'échange s'inscrit dans un lieu concret-la halle aux grains, les marchés périodiques, les foires ... -régi par des contraintes précises... qu'il peut créer des prix, expression de la confrontation physique d'une offre et d'une demande. L'échange dans l'Ancien Régime est d'abord un réalité matèrielle. C'est aussi cette dimension concrète et répétitive de l'institution de marché qui permet l'apprentissage des comportements et la reconnaissance tout empirique des configurations de marché, deux préalables à la cohérence des échanges.”

${ }^{8}$ Malanima, 'Italian Cities 1300-1800,' 118.

${ }^{9}$ Malanima, 'Italian Cities 1300-1800,' 104.

${ }^{10}$ Malanima, 'Italian Cities 1300-1800,' 104: “The urban perchange was high in the Venetia too, even if lower than in Tuscany, it was, however superior to that of the western Po Valley and Piedmont.”

${ }^{11}$ In general on this subject see Ginatempo and Sandri, L'Italia delle città, 7389; on the centres of the Marca Trevigiana in relationship with the Venetian mainland see Varanini, 'Le città della Marca Trevigiana.'
} 
is calculated that Venice's inhabitants numbered more than 100,000 and, together with Genoa, Milan and Florence, had the largest urban population in Italy, matched in Europe only by Paris. From a commercial point of view, Venice had extended a kind of economic protectorate all along the Adriatic coast and along the rivers of the region. Furthermore, during the fourteenth century the network of Venetian merchants effectively advanced in the region of the Po and in this way increasingly subjected all the hinterland cities, drawing into its orbit the Treviso economy, which without Venice would have been unable to sustain it own development.

From an economic viewpoint, by the mid-thirteenth century Verona, with its 35,000 inhabitants, could boast in comparison with other cities an early development of its manufacturing activities, in particular its wool and cotton textiles. This was due to the superiority of its technical performance and to its manufactured goods, whose market extended beyond the regional boundaries. The town's superiority was to a large extent affected by the geography of the great international trade routes. In fact, it can be claimed that its early manufacturing development and its commercial network sustained each other in supporting the supremacy of Verona. The role of the Adige River and of the strata de ultramonte as routes for transporting Veronese products independently of Venice itself not only towards the north to Germany, but also towards the south along the Adriatic was fundamental. ${ }^{12}$ Venice's commercial policy in the Po area in this period had, anyway, encouraged the Veronese elite to sign a series of treaties for the joint control of the rivers of the Adige valley.

These relations were destined to last and, already at the beginning of the fifteenth century, were of crucial importance when Venice was extending its political domination in the region, completing it with the conquest of the Lombard cities of Brescia, Bergamo, and Crema and of the region of Friuli. ${ }^{13}$ Throughout the rule of Doge Francesco Foscari (14231457), Venice's objective was the conquest of Milan, its arch-rival in northern Italy. However, its ambition to expand towards Lombardy ended in 1449 when the acquisition of Crema completed the mainland Venetian state.

From a political point of view, the fact that the elite of the Venetian government failed to integrate in the long term with the governing elite from the subject cities was a characteristic of the very nature of the state which was modelled on the supremacy of the ancient comune veneciarium. ${ }^{14}$ From an economic point of view, the survival of structures connected to an urban economy, that is, the maintenance of an autonomy and vitality that depended on their role in any particular territory, seen as a geo-economic rather than as a political entity, ${ }^{15}$ hindered the establishment of a regional

\footnotetext{
${ }^{12}$ Varanini, 'Le città della Marca Trevigiana,' 132-133.

${ }^{13}$ Cozzi and Knapton, Storia della Repubblica di Venezia, 205-230; Knapton, 'La terraferma,' 165-173.

${ }^{14}$ On this subject see Knapton, 'Nobiltà e popolo’and the rich bibliography cited.

${ }^{15}$ Lanaro, I mercati della Repubblica Veneta, 41-52.
} 
market within the state that now had a political definition. ${ }^{16}$ The very acts of loyalty professed by individual cities in order to avoid the consequences of military conquest became political instruments that were an expression of the desire to legitimise the rights and privileges that differed for all the subject cities, ${ }^{17}$ but in any case tended to defend consolidated economic autonomies.

Consequently, there was no uniform trend on the Venetian mainland. The towns geographically closest to Venice, such as Treviso, with only a modest manufacturing development, in the long run consolidated their subordination to Venice, which had existed for many decades. The same is true for Friuli, a region with only a few urban settlements. On the contrary, cities in Lombardy, such as Brescia, Bergamo, and Crema, farther from Venice and at the same time nearer to Milan and to the port of Genoa, found themselves at the centre of a productive and commercial network that freed itself, although to different degrees, from the allure of Venice and so it was in this direction that they tended to move even in their Venetian period.

The position of Verona is anomalous and can be defined as borderline in so far as it shared historical-economic affinities both with the Venetian and the Lombard areas. ${ }^{18}$ Its specific geophysical reality in a border area and on the Adige River, a watershed between two regions and at the same time an important trade route between the towns of the centrenorth of Italy and the states of the centre-north of Europe, as well as its vicinity to Milan, meant that Verona did not consider Venice as its only port to the sea. It maintained with some changes its old trade network linked to its history as a flourishing urban economy, actually becoming-in competition with Venice itself-a strong attraction for nearby towns, in particular for Vicenza.

b. The Fifteenth Century. The Demographic Situation and Economic Hierarchies: The Survival of City Economies

The lack of economic uniformity, confirmed by the demographic situation, shows interesting quantitative differences between the various subject cities. It reaffirms the spatial division within the state of Venice and, albeit in ambiguous terms, highlights areas of major development. Even though we cannot assume that a demographic scale corresponds to other scales, in this case economic ones, the demographic situation is part of the inescapable data necessary for understanding the existence of systemic structures. In the thirteenth and fourteenth centuries, Brescia and Verona already played a leading role in the multi-centrality that had long been a feature of the area. Despite the vacuum created by the fourteenth-century plague epidemic, in the fifteenth century these two cities still stood out in

\footnotetext{
${ }^{16}$ On the duration of the regional models and of spatial divisions and on the complexity of the reasons on which they are based see Prak, 'Regions in Early Modern Europe,' 40-43.

${ }^{17}$ Ventura, 'Introduzione,' 5-15.

${ }^{18}$ Cozzi, Ambiente veneziano, ambiente veneto, 297-298.
} 
Italy and in Europe for their population density, with 40,000 inhabitants, as can be seen from map 1-2-3, numbering them at the end of the century among the villes-géants. ${ }^{19}$ The leadership of Venice, with its population of around 82,000 in 1422, shows a demographic superiority whose power of attraction was not slow to be felt.

In the Venetian state in the fifteenth century, the preservation of certain privileges in the economic ambit—and, in particular, as we will see, in commerce, above all by those cities which were politically and economically better organized-confirms the vital survival of urban economies within the state, even though Venice still seemed to be uncertain about possible plans by the subject cities of Lombardy to penetrate and control important trading with the Duchy of Milan. This climate of uncertainty helped the old city economies that had been able to exploit structural features, such as a network of rivers or roads, the proximity and complementary nature of markets on the other side of the Alps, or rich sources of water in the pre-alpine belt, to create economic areas that consolidated market trade circuits based on the integration of markets at a distance from each other. ${ }^{20}$ The raw materials and industrial goods, mainly textiles from the countries of Central Europe, of the German area, but not exclusively, were exchanged with industrial products of cities at the centre of such a system and with raw materials from Southern Italy and countries of the Mediterranean basin. It is hardly surprising that this vitality is clearly apparent in the case of Verona and to a lesser degree in that of Brescia. With their wide entrepreneurial trade network, these two important textile manufacturing centres in the heart of economic areas-Brescia was also important for metal-working-were able to function autonomously from Venice, Verona more so than Brescia. ${ }^{21}$ In fact, they obtained the privilege of being able to choose freely the routes along which their goods could pass, Verona in complete freedom, Brescia with some restrictions. In other words, the merchants of the two cities were allowed to export and import goods along the route they deemed best without respecting the general rules applied in the Republic for the Rialto port, whose aim was to control the payment of duties and to ensure the use of Venetian shipping, mostly owned by the leading families of the Venetian aristocracy. ${ }^{22}$

The other strong point of the agreements between the centre and periphery allowed the most important conquered cities to host fairs, gatherings that were legally exempt from any taxation, at least for a certain number of days or for certain goods. ${ }^{23}$ This, however, was the first privilege to be subject in the long term to difficult negotiations that led to its abrogation. The privilege accorded to fairs themselves was debated only at

\footnotetext{
${ }^{19}$ Ginatempo and Sandri, L'Italia delle città, 213-215.

${ }^{20}$ Lanaro, I mercati della Repubblica Veneta, 41-52; Varanini, Comuni cittadini e stato regionale, 331-360.

${ }^{21}$ Lanaro, 'Economia cittadina'; Pegrari, Il "continuo giro et moto,"' 21-37; Demo, "Da Bressa se traze panni fini."

${ }^{22}$ Lanaro, 'I rapporti commerciali tra Verona e la Marca anconetana,' 9-25, Lanaro, I mercati della Repubblica Veneta, 53-74.

${ }^{23}$ Lanaro, 'Periferie senza centro,' 22-28.
} 
the end of the eighteenth century when the ideas of French thinkers on the subject of economic freedom began to circulate. This privilege was, however, not abolished, as it was considered to be an unalienable right of the cities.

The concession of privileges ratified by the central authority was sometimes interpreted as an element of political weakness on the part of the state and, in economic terms, as a sign of institutional backwardness. This theory was refuted by S.R. Epstein, who stressed that its use can be viewed as a consequence of the fact that the state monopolized the rights of the market. ${ }^{24}$ This seems to be the case with Venice. The primary economic interest of the Republic was in maritime trade, which was protected by restrictive measures that were all punitive for the subject cities, while less attention was paid to the manufacturing sector and to internal trade. The result was that, for the entire fifteenth and part of the sixteenth centuries, the city economies, with the populous cities of Verona and Brescia at the forefront, continued to make their protests felt. However, the financial and commercial crisis that beset the Republic following the defeat of Agnadello (1509) brought about a change. Venetian leaders decided in those years, even though confusedly, to reorganize the economy, adopting a policy encouraging the flow of trade linked to a tariff policy basically aimed at favouring a constant flow of money towards the capital and at protecting the centre and the Rialto market as the hub of the entire state economic system. $^{25}$

\section{Trade” \\ c. The Capital and Privileges of the Subject Cities: "Tricks of the}

Venice's empirical policy tended to favour the proliferation of concessions, awarding exemptions and privileges to individual communities. The fortuitous way these grants were applied, in a short while brought about the collapse of the project and the formation of areas within the state which, subjected to centrifugal forces that arose from unpreventable historical events, only marginally interacted in economic terms with the state itself. Thus, the role played by the network of fairs, mutatis mutandis, becomes an essential feature in the consolidation and maintenance of ancient economic areas which at first found support in independent routes. Communication networks not obliged to pass through the compulsory port of the Rialto interacted with outlets for the sale and acquisition of goods like fairs, exempt from duties. In this way, it was possible to maintain the old economic areas, those not swept away by the winds of change, and to set up other areas that could communicate with consolidated merchant networks. The freedom given to individual fairs enabled the merchants and the merchant entrepreneurs of the mainland, who were fully aware that this system of exchange would help lower the costs involved in transactions, to organize economic opportunities using new and

\footnotetext{
${ }^{24}$ Epstein, 'Strutture di mercato'; Epstein, Freedom and Growth, 12-37

${ }^{25}$ Lanaro, I mercati nella Repubblica Veneta, 86-95.
} 
old methods. The calendar of these fairs linked in one network the fairs of the territory, especially those of the pre-alpine belt to those along the Adriatic coast - a launching pad towards the markets in the south of Italy and those in the Levant-and to the alpine and transalpine areas.

The modified demographic picture that registered a recovery after the seventeenth-century plague, predominantly in the countryside rather than in the towns, including Venice itself, as table 2 illustrates, and the spread of proto-industrial activity in rural areas consolidated the separation from the capital. This was part of a process of symbiosis between networks of merchants that operated on a regional basis, sometimes without intermediaries from the city, and the spread of territorial fairs, above all in the pre-alpine belt, as in Vicenza, which led to the establishment of areas that acted more and more autonomously.

At the same time, there was a choice of industrial regulations aimed at protecting certain sectors connected to the capital or aimed at favouring a trend leading to specialization and diversification between the capital city, the subject cities, and the rural areas in the production of manufactured goods-especially in the silk sector. This choice seemed to be still constrained by the dominant role of the ancient comune veneciarium, its governing elite, and its inhabitants, rather than being concerned with a general project that would embrace the whole of the state economy.

Long established itineraries that gave a wide berth to the Rialto port had been suppressed, but were still illegally in use. By-passing the capital in this way can be explained by the power of attraction of the wealthy subject cities in the western Veneto and in the so-called Lombard-Veneto area interested in the Milan market and also in fairs free from the usual duties: all these aspects contradict any theory of the formation of an economic region in the Venetian state. This differed from other situations in Italy, such as in Tuscany and Piedmont, ${ }^{26}$ but above all from situations in other parts of Europe where the formation of nation states gave rise to national economic systems that had the capital city at their core-suffice it to mention France. ${ }^{27}$ The example of the Veneto encourages the study of interacting economic areas, the result of merchant networks that were able to exploit structural features and ambiguous political freedom. They naturally respected the Venetian monopoly over the great maritime trade, essentially one in transit, which was invariably and firmly in the hands of the great families of the lagoon city.

d. From the Sixteenth to the Eighteenth Centuries. Réseaux marchands and Trade Circuits

In the modern age, two areas progressively came to be defined as a system. The first had the city of Verona at its core. Already in the Late

\footnotetext{
${ }^{26}$ Malanima, 'Politica ed economia,' 131-172; Levi, Centro e periferia di uno stato assoluto.

${ }^{27}$ Genet, 'La genèse de l'état moderne,' 3-18. See also Levi, 'The origins of the Modern State,' 53-82.
} 
Middle Ages its powerful mercantile elite had consolidated a trade circuit that extended from the countries beyond the Alps to the south of the Italian peninsula and to the Balkans, thanks to the role that the Adriatic fairs played as intermediaries. At the beginning of the seventeenth century, the Veronese organized an efficient system of fairs in Verona itself, which included fairs for trade in goods (fiera merci) and in money (fiera di cambio), while at the same time drawing into their orbit the fairs of Bolzano ${ }^{28}$ and of Vicenza. This network also comprised the fair of Senigallia, which from the seventeenth century, as far as turnover was concerned, took the place of the small fairs along the Adriatic and became their preferred trading place with the East and the Mediterranean area in general. If the structural crisis of the European economy and the population expansion of the sixteenth century forced a change in the manufactured goods of the city, from a social point of view the process of transforming the governing elite of Verona into an aristocracy meant that instead of investing in goods and manufactured products, investments were in land. ${ }^{29}$ A new class of merchants took over from the old group specializing in the production and commercialisation of new products such as knitted goods, berets, semi-finished silk goods, and raw silk, which enabled both old and new markets to keep functioning. ${ }^{30}$

In the case of Verona, new merchants and new products continued to move within strong commercial circuits, whose attraction extended to Vicenza, so much so that merchants from Vicenza decided to favour the markets of northern Europe. If in the fifteenth and sixteenth centuries the rural areas around Vicenza saw a considerable development in the production of woollen cloth of an inferior quality, we know that commerce in these products was mainly controlled by Venetian merchants. When silk yarn and textiles, ${ }^{31}$ now manufactured in urban centres, became the primary product, Venetians were progressively marginalized, while the merchants of Vicenza, often members of the governing elite, took over the trade monopolies, penetrating especially the English, German, French, and Dutch markets. A sign that a significant change had taken place and that the merchants had broken away from the capital is the fact that semi-worked silk products manufactured in the area of Verona, whose quality was inferior to that of Vicenza, were anyway traded with those of Vicenza. The two mainland towns not only acted together, but both preferred to intensify their trade links with the markets of Northern Europe.

It is interesting to note that the consolidated circuits and the old trade networks disprove the traditional theory of an Italy cut in half between north and south. A more plausible theory would see a division between western and eastern areas along the Apennine chain. This idea of a line of division along the Apennines is confirmed by the limited trade relations between the

\footnotetext{
${ }^{28}$ Relazioni dei Rettori Veneti in Terraferma-Podestaria e Capitanato di Verona, report of Girolamo Corner dated 1612, 205-206.

${ }^{29}$ Lanaro, “"Essere famiglia di Consiglio,”" 428-438.

${ }^{30}$ Lanaro, 'I rapporti commerciali tra Verona e la Marca anconetana,' 9-25; Belfanti, 'Maglie e calze, '583-594; Varanini and Lanaro, 'Egemonia sul territorio,'33-68.

${ }^{31}$ Demo, L'anima della città, 307-320; Vianello, Seta fine e panni grossi.
} 
Adriatic and the Tyrrhenian coast: the two coasts traded more frequently with their foreign counterparts than with each other. ${ }^{32}$ In this geographical division, the réseaux marchands from Venice and the Veneto area (not forgetting that the latter mainly traded with markets opened by the former) extended towards the areas of the Adriatic, ${ }^{33}$ the Levant, and the Near East. In the fairs scattered along the coast, such as those at Recanati, Fano, Lanciano, and Senigallia, they traded manufactured goods produced in the city workshops or in part imported from continental Europe along with the raw materials, which were essential for the urban industries, like leather, wool, dyes, oil, wax, cereals and agricultural products, and others of considerable value from the East.

The Lombard area had a network of fairs that had at its centre the great fair of Bergamo, the most important sixteenth-century fair in Italy. The powerful Bergamo merchants, mostly involved in textiles, wool, but also hemp and linen and later silk, and progressively in metal work, made the fair the hub of their international dealings. It extended in all directions from the Rialto and the Veneto markets to those beyond the Alps and to Lombardy. However, during the seventeenth century it was Milan which mostly attracted the Bergamo merchants. The capital of Lombardy became the main market for sorting and linked Lombardy to Genoa, Geneva, and Lyons, becoming a centre for the procurement of supplies for neighbouring countries. ${ }^{34}$ The Bergamo merchants also managed to maintain a presence in the east, availing themselves of the same contacts and merchant networks as the Brescian operators. The latter's organization and financial capability, at least in the eighteenth century, was totally subordinate to the Bergamo merchants, or rather to the merchants operating in Bergamo, characterized already in the seventeenth century by an enterprising minority of Swiss merchants. ${ }^{35}$ A circuit of fairs became operative and included the Bergamo Fair of Saint Alexander that, together with the fair of Senigallia, was the most important one in eighteenth-century Italy, in a short time drawing into its orbit the fairs of Brescia, Bolzano and Senigallia itself. This circuit was at the centre of a mercantile network whose hub was Milan, both as a sorting centre and as what was to become an important financial market, and which included Genoa, whose port was competing more and more with that of Venice. From the seventeenth and eighteenth centuries a process of regionalization took place in the Lombard area, which re-proposed a return to the boundaries of the Lombardy of the Visconti. The Bergamo and Brescia areas ${ }^{36}$ became the eastern borders in that process of consolidation, which in time shifted away from Venice, but certainly steps had been taken to hasten the change in the balance of power from the Mediterranean to the Atlantic.

\footnotetext{
${ }^{32}$ Lanaro, 'Economic Space and Urban Policies'; Galli Della Loggia, L'identità italiana, 7-30.

${ }^{33}$ Moroni, 'Mercanti e fiere tra le due sponde dell'Adriatico.'

${ }^{34}$ Relazioni dei Rettori in Terraferma-Podestaria e Capitanato di Bergamo, report of Nicolò Donato dated 1627, 444.

${ }^{35}$ Mocarelli, 'L'economia bergamasca nel settecento.'

${ }^{36}$ Mocarelli, 'Alla periferia di un'economia regionale.'
} 
3. Urban Manufacturing and Proto-Industry: A New Historiographic Approach to the Republic of Venice

a. International Commerce and Urban Manufacturing. The Diversification of the Investments of Venetian Merchants

The Venetian Republic is still considered to be one of the first European state to accept the drastic change in mentality and in capitalistic practice brought about by the great maritime commerce between the Levant and the East, above all in terms of international commerce in transit. ${ }^{37}$ According to the theories of Braudel and de Vries, it is commercial factors that are the basis of urban development in Medieval Europe. ${ }^{38}$ According to this model, the autonomy and the power of the principal cities and the key role played by the Mediterranean in trade between Asia and Europe conditioned the system of urban Europe. These factors created a multicentral network within Continental Europe, in which Venice, together with Genoa, Milan and Florence, placed themselves as leaders in Southern Europe, while Bruges and Antwerp assumed a similar role in North-Western Europe. ${ }^{39}$ This explains why great attention has been paid to Venetian merchants such as Sebastiano Ziani, Andrea Barbarigo, Francesco Balbi, Giacomo Badoer and Federico Corner, an economic but also a governing elite. This was because with the lock-out by the Maggior Consiglio, the main Venetian families who obtained their wealth from maritime commerce brought about a real coup d'état which transformed them into an hereditary aristocracy.

Italian and American historiography, particularly in the midtwentieth century, carried out thorough studies of the figure of the Venetian merchant, reconstructing his performance in the East and the West and, to a lesser degree, in the North and the South, in a labyrinth of private and public interests, of policies and practices, highlighting his contribution to the implementation of the principles of double entry book keeping on which modern business accounts are based, an essential instrument of management in the establishment of the capitalistic spirit. By carefully analysing archive sources Gino Luzzatto, the founder or at least one of the founders of Italian economic history, stepping expertly into the debate initiated by Weber and Sombart on the birth of capitalism, made a notable contribution to the study and reconstruction of the great figures at the beginning of commercial Venetian capitalism, in particular in the thirteenth and fourteenth centuries,

\footnotetext{
${ }^{37}$ Braudel, Civilisation matérielle, économie et capitalisme, 3:137-153.

${ }^{38}$ Braudel, Civilisation matérielle, économie et capitalisme, vol. 1; De Vries, European Urbanisation 1500-1800.

${ }^{39}$ For how the theories of Braudel and De Vries (but not only them) were applied in the Low Countries, see Van De Wee, 'Industrial Dynamics,' 307-312.
} 
centuries which saw the birth of capitalism. ${ }^{40}$ On an international level the contribution made by the studies of Fredric Lane, a friend and also partly a student of Luzzatto, at least in so far as the knowledge of the wealth of documentation kept in the Venetian archives of the Frari is concerned, confirm this approach to the study of Venetian history. This resulted in a series of research projects that contributed to publicizing the image of Venice as the cradle of dawning capitalism. ${ }^{41}$ In addition, Luzzatto's studies established the supremacy of international commerce over Venetian industry itself in the period in question; in fact, Venetian industry was slow to develop on account of protectionist measures decided by the great merchants in favour of international commerce. Both in Italian and international historiography this theory time has met for a long with the approval of historians and has contributed to stressing the connection between Venice and the great commerce between East and West during the Late Middle Ages.

This interpretation was further strengthened by the change in the economic situation on the continent from a multi-centred to a mono-centred structure, whose primary interest was the Atlantic, with Amsterdam and a little later London as the dominant cities, and which experienced its key period from 1600-1650. It was at this time that the commercial centre of gravity in Europe shifted from south to north, with a complete reorganization of the urban structure in Europe, now dominated by one city, London. Venice was relegated to the margins of the new world, which was organized around the ports facing the Atlantic, principally around the great capital cities and the key markets of Amsterdam and London. The city, which thanks to the birth of commercial capitalism had been at the heart of the medieval economy, in this new phase dominated by commercialfinancial capitalism slid towards the periphery. In the new division of labour set up on the European continent, the north and centre of Italy, and consequently Venice and Veneto itself, were assimilated into the Mediterranean area, which was geared to the production of cereals and raw materials for export to developing countries such as England or the neighbouring Germanic states. ${ }^{42}$

In social-cultural terms, the Italian elite, who had made manufacturing and commerce the driving force of their social growth, abandoned the traditional sectors of investment in favour of land. ${ }^{43}$ By turning into great landowners, the urban patriciate of Central-Northern Italy attempted to assume a lifestyle typical of the continental aristocracy (more nobilium).

This historiographic theory, which married cultural to economic theories, met with considerable approval. In recent years, however, studies have considerably modified the dramatic tone of this change, which was

\footnotetext{
${ }^{40}$ Luzzato, Storia economica di Venezia, 29-132; Luzzato, 'Les activitiés économiques du patriciat venitien.'

${ }^{41}$ Lane, Venetian Ships and Shipbuilders; Lane, Andrea Barbarigo; Lane, Venice A Maritime Republic.

${ }^{42}$ Cipolla, 'The economic decline of Italy.'

${ }^{43}$ Jones, 'Economia e società nell’'Italia medievale,' 337-372
} 
expressed in different ways according to specific urban situations. In the case of the Veneto, the interest in land investment, which sometimes had capitalistic overtones - it is enough to mention land reclamation and the propagation of rice cultivation ${ }^{44}$-involved the Veronese patriciate, who in the late sixteenth century were largely replaced by new figures from the business world. In the case of Vicenza, many leading figures of the governing elite, from the Capra to the Thiene, from the Trissino to the Godi, the Piovene and Valmarana, at the end of the sixteenth century still seemed to be directly involved themselves, along with front men, in business and commercial activities, principally in silk manufacturing. ${ }^{45}$ The interest of the Venetians, whether or not politicians, in acquiring land, a choice conditioned by economic needs as well as by political ones, did not, by and large, distract them from their mercantile and business concerns. ${ }^{46}$ This is a field that requires further studies, but certainly eighteenth-century studies have brought to light significant cases of noblemen who were landowners, merchants, and entrepreneurs. The figure of Nicolò Tron, a member of an important Venetian aristocratic family, is a case in point. He is well known for having set up a wool textile factory at Schio in 1718.

Once again, it seems to be the silk sector, with its roots both in agriculture and manufacturing, which occupied the Venetian nobility in the virtuous activities of "industry in villas". If the answer to the crisis of wool mills in the subject territories was their conversion into silk mills, the primary result was the propagation of the cultivation of mulberries and silk worms in the country. In this sense, Venetian noblemen acted in line with those from subject cities. In fact, in a treatise written during the eighteenth century, Benedetti was to make the following comment about Senator Leonardo Dolfin "dilettantissimo ne (i gelsi) fece porre da per tutto nelli suoi prati, e in molti alti siti delle sue campagne" ${ }^{\text {"47 }}$ (a complete amateur, he had mulberries planted in all his fields and in many other places on his land). On the other hand, it was the Contarini, Venetian noblemen, in their villa at Piazzola on the Brenta River, near Padua, which is still intact today, who initiated one of perhaps the most impressive experiments of "industry in villa", obtaining permission to build an "Edificio a orsoglio alla Bolognese" and setting up a production of silk that included spinning as well as silk reeling (and also the phase of spooling), with a definite saving in costs and in time. ${ }^{48}$

\footnotetext{
${ }^{44}$ Ventura, 'Considerazioni sull' agricoltura veneta.'Emblematic of this new spirit is the case of Marcantonio Serego: Borelli, 'Terra e patrizi nel XVI secolo: Marcantonio Serego'; Lanaro, Un'oligarchia urbana nel cinquecento veneto, 244256.

${ }^{45}$ Demo, 'Le manifatture tra Medioevo e Età Moderna,' 61.

${ }^{46}$ Beltrami, La penetrazione economica; Gullino, 'Quando il mercante costruì la villa.'

${ }^{47}$ Benetti, L'accorto fattor di villa, capo LV, or the spread of silk production on the mainland in the sixteenth and seventeenth centuries. Molà, The Silk Industry of Renaissance Venice, 217-236.

${ }^{48}$ Biblioteca Nazionale Marciana, Venice, ms It. VII, 1932 (90-58) “Cassa contanti di ragione del negozio seda” (ms. dated 1745); see Lanaro, 'Il contesto
} 
It is not surprising, then, that for Venice the concept of relative, rather than an absolute decline, already espoused by Gino Luzzatto ${ }^{49}$ and later developed by Richard Rapp, ${ }^{50}$ along with others, continues to be confirmed by the study of new documentary sources. This is in line with studies of the whole of the Italian peninsula in the seventeenth century. Today these studies are re-evaluating the economic trends of the late seventeenth century, registering recovery following the dramatic years after the outbreak of plague in $1630 .^{51}$ Thus, the fact that recent historiography has extended its interest from Venice to the terra firma and consequently to the economic interaction between Venice and the rich and populous subject towns, has contributed to elaborating a more balanced view of the economic process begun at the start of the modern age. The relationship between centre and periphery, between Venice and various regional areas within the state, comes to life in a scenario that combines the commercial as well as the manufacturing and agrarian situations. It is a view that embraces all mainland Veneto: the negative cycles of certain industrial and/or commercial sectors of Venice throughout the seventeenth century can be matched with positive cycles in the same sector or in adjacent sectors of the subject lands and in particular areas of the dominion.

Accordingly, not only the currently highly criticized myth of the decline of Venice proves to be flawed, but the idea of a relative decline no longer appears methodologically satisfactory. ${ }^{52}$ The studies included in this volume are an invitation to read in a new light the role and position of Venice within the European economies of the time. This does not mean to focus on its downfall but, on the contrary, to concentrate on how the Venetian economy was able to react and adapt itself to the new and different international economic trend.

Studies not only of Venice, but also of mainland Veneto, enable us to formulate a view of the Venetian economy which contributes to integrating the traditional - but today inadequate- view of relative decadence, in particular the view espoused by Richard Rapp, who limited himself to examining the situation in the capital and its merchants. Venice's answer to the new equilibrium of world economy depended more and more

economico e territoriale,' 151-153 for a comment on "industria in villa”; for the Bolognese mills, see Poni, 'Archéologie de la fabrique.'

${ }^{49}$ Luzzatto, Per una storia economica d'Italia, 156-171.

${ }^{50}$ Rapp, Industry and Economic Decline.

${ }^{51}$ Malanima, La fine del primato; Sella, L'Italia nel Seicento.

52 "Economic technicians, particularly from England and America, saw in Venice an interesting case study in arrested and reversed economic development, an instructive counter example to prevailing models of economic growth. Yet, despite diverging intentions, the debate has seen a broad consensus of method and intention. To locate flaws in Venetian economic and political structures and thereby assign blame for the fall from a universally presumed golden age" in Grubb, 'When Myths Lose Power: Four Decades of Venetian Historiography,' 61. Grubb's comments have been reiterated in general terms in Martin and Romano "Reconsidering Venice", the introduction to the volume Venice Reconsidered, where, however, the economic element is marginal to their considerations. 
on the merchants and merchant entrepreneurs, a class made up of men both from Venice and the terra firma, who worked in conjunction one with the other. In Venice many leading figures from the mainland interacted with Venetians in an effort to provide fresh impetus to urban manufacturing, adapting it to a changing market. On the mainland, whether or not they were members of the nobility, Venetians and merchants from the Veneto were, either themselves or through third parties, involved side by side in investing and organizing the development of new sectors. They dealt not only with the production and commercialisation of silk goods and knitwear, such as berets, but also in ceramics and metalwork.

\section{b. Venice as an Industrial City: Growth in the Sixteenth Century}

In recent years, studies have reconstructed the "industrial" dimension of Venice in the sixteenth century and the first decades of the following century. They have gone beyond the traditional view of the role of that great state enterprise, the Arsenale, considered to be the first kind of business enterprise in the western world. ${ }^{53}$ With Europe's centre of gravity moving from the south to the north and the discovery of new geographical routes, the Mediterranean became a sea with secondary importance; the Rialto thus suffered threatening competition from the Atlantic powers in the economic field that it had dominated for centuries, that is, commerce with the Orient. The inability of Venetian merchants to rise to the challenge in competitive terms contributed to limiting their scope for manoeuvre both in quantitative and qualitative terms. However, it is extraordinary how the city evolved from the end of the fifteenth century to become an industrial centre in the sixteenth century, probably the first industrial centre in Europe according to Braudel. ${ }^{54}$ While maintaining a considerable amount of business connected with its great maritime commerce, the industrial system of the city, far from being a last resort, further strengthened its economy. This peaked in the fifteenth and sixteenth centuries and meant that Venice was respected in almost all the key manufacturing sectors in the late Middle Ages. ${ }^{55}$ In answer to the structural changes in the balance of power in Europe, businessmen from Venice and the Veneto opted for the manufacturing sector; the subject, though, is still uncertain and requires further specific research. In these centuries in many urban economies from Flanders to Florence and from England to Lombardy the wool industry was in the lead. From the fourteenth century it also took root in Venice without being unduly hampered by the restrictive regulations designed to favour commerce between Asia and Europe. From the fifteenth century the magistracy of the provveditori di comun (the magistracy supervising the wool guild) introduced a series of incentives in favour of those who exported the largest number of medium-quality Venetian cloths, making

\footnotetext{
${ }^{53}$ Lane, Venice: a Maritime Republic, 362; on the shipbuilding industry in general see Lane, Venetian Ships and Shipbuilders of the Renaissance.

${ }^{54}$ Braudel, Civilisation matérielle, 3:157.

${ }^{55}$ Ciriacono, 'Industria e artigianato.'
} 
commerce the prime backer of Venetian industry, in this sense refuting Luzzatto's accepted theory. ${ }^{56}$

The great international maritime commerce remained firmly in the hands of the governing elite, the exclusive monopoly of the class of native Venetians, and so can be branded inflexible and exclusive. On the contrary, the manufacturing sector of the city, whose population between 1560 and 1570 was around 170,000 inhabitants (very near its 1606-07 peak of $190,000),{ }^{57}$ took root and expanded partly thanks to a mercantile policy that deliberately defended Venetian goods and partly thanks to a notable social opening that enabled entrepreneurs and artisans of whatever origin, either Venetians, men from the Veneto, or "foreigners" to employ freely their ingenuity, capital and labour.

Unlike in other European contexts, in Venice the guilds were not subject at the outset to clauses requiring members to be native Venetians nor to carry out a particular kind of work; they actually allowed the creation of associations composed exclusively of foreigners, like the German gold beaters and the porters from Bergamo. A city of foreigners, as Philippe de Commynes commented, ${ }^{58}$ Venice shunned the idea of identifying citizenship with membership in a guild. It was only in the latter period of its history, following the plague of the seventeenth century that brought about a change in the organization of the urban industrial system, a typical feature of the centre-north of Italy, that manufacturing suffered a crisis and closed some of its doors to recent immigrants. On the other hand, a bulwark of Christianity against the advance of the Turks like Venice could not but unreservedly welcome Christians who had abandoned countries under Islamic law. If in the late sixteenth century there were episodes when foreign workers within specific guilds were attacked, as happened in the case of the bakers and later the shoe-makers, these incidents are to be explained not so much as a xenophobic reaction, but as the result of a change in working relationships between entrepreneurs and workers. The businessmen put into effect in urban industry the capitalistic methods that had for a long while been consolidated in the commercial sector. They questioned the medieval organization of work based on the artisan's workshop where masters, workers and their apprentices all shared the view that the employer should behave like a good father to his family. ${ }^{59}$ It was Venice's ability to attract to its islands a varied cosmopolitan population that brought with it not only its technical skills, but its colourful variety of artistic tastes that proved to be crucial for the development of manufacturing as well as for the artistic development of the city. In a city where knowledge was transmitted by the mobility of craftsmen and "engineers," rather than by

\footnotetext{
${ }^{56}$ Mozzato, L'arte della lana a Venezia nel basso medioevo, 218-219.

${ }^{57}$ For a comment on the demographic sources for the period 1500-1600, see Favero, Moro, Spinelli, Trivellato and Vianello, 'Le anime dei demografi.'

58 "Most of the population are foreigners" (Philippe de Commynes, quoted in Cozzi-Knapton, La Repubblica di Venezia nell'età moderna, 148). On foreigners in Venice see Lanaro, 'Introduction,' 156-158.

${ }^{59}$ Della Valentina, 'I mestieri del pane a Venezia,' 178-192; Vianello, L'arte dei calegheri, 105-128.
} 
the circulation of manuals and books, often incomplete in their technical descriptions and rapidly out-of-date, cognitive localism according to S.R. Epstein was the biggest bottleneck to technical progress and could be overcome only by the permanent migration of master craftsmen and the temporary migration of paid workers. ${ }^{60}$ In other parts of Europe, it was only in the seventeenth century, under pressure from the mercantile states, that permanent migration became more systematic. Venice, on the other hand, already in the fourteenth century through its fiscal, business and social measures had favoured a permanent settlement of foreign craftsmen with their knowledge of technologies then underdeveloped in the city. Its policy in favour of the artisans from Lucca is well-known. These craftsmen, who had emigrated for political reasons, transferred to Venice the techniques used in the manufacture of silk, laying the foundation for its manufacture, so that when the crisis in the wool sector arrived, silk manufacturing was destined to become the most important "industry" of the city. ${ }^{61}$ The role of Greek technicians in the shipyards of the Arsenale is also well-known. ${ }^{62}$ As elsewhere in Europe, the corporations consolidated their knowledge of the various productive processes and made sure that it was kept and transmitted from one generation to another, defending it with careful and jealous policies. In this way, institutions hostile to radical innovation were favoured. However, the city government was ready to secure the services of anyone who was able to set up innovative manufacturing, fuelling in this way a lively activity of industrial espionage. ${ }^{63}$

The reluctance of the guilds was balanced by the city administration's prerogative to grant licences, monopolies and patents. Artisans and technicians who proposed the introduction of processes and products that were unknown in Venice were awarded patents. Because of this, they were unlikely to come into conflict with the artisans' guilds. ${ }^{64}$ When this happened the clash was not so much with artisans' guilds as with the merchants' corporations. Such was the case with the technique for dyeing silk patented at the beginning of the eighteenth century by the Florentine Cosmo Scatini. He envisaged a centralized dyeing centre and this encountered the opposition of the corporation of the silk merchants, who feared that artisans would gain the upper hand over the merchant class. ${ }^{65}$ In the case of Venice, corporative organizations and the system of licences performed different functions in the same institution.

Shipbuilding was the commercial backbone of the Republic and, according to Robert Davis, provided for about $10 \%$ of the population. ${ }^{66}$ The Republic identified itself with the Arsenale and its activity was protected for a long time by measures taken by the state, measures often dictated more by diplomatic and political concerns than by economic policy. This, however,

\footnotetext{
${ }^{60}$ Epstein, 'The Generation and Transmission.'

${ }^{61}$ Molà, La comunità dei lucchesi a Venezia, chapts. 4-5.

${ }^{62}$ Aymard, 'Strategie di cantiere,' 280.

${ }^{63}$ Preto, I servizi segreti di Venezia, 381-401.

${ }^{64}$ Belfanti, 'Guilds, Patents, and the Circulation of Technical Knowledge.'

${ }^{65}$ Berveglieri, 'Cosmo Scatini e il nero di Venezia.'

${ }^{66}$ Davis, Shipbuilders of the Venetian Arsenal, 'Introduction.'
} 
contributed in no small way to discouraging private shipbuilding. From the fourteenth to the sixteenth centuries the merchant fleet of private ship owners was larger than the military and merchant galleys built by the state, but the private shipyards started their decline from the second half of the sixteenth century. This was not only due to the decisions taken by the Venetian authorities, for example on the question of importing raw materials, but also as an effect of a more general transformation of the Venetian economy, which suffered by comparison with the more economic production by new competitors in various sectors, including shipbuilding. ${ }^{67}$ The Arsenale itself reached its moment of glory with the battle of Lepanto (1571), even though recent studies underline a certain recovery in its activity after the critical years at the end of the sixteenth and the first half of the following century.

Besides shipbuilding, the first manufacturing enterprise to assert itself was the wool industry, though unlike Florence's wool industry, it became neither the driving sector nor the centre of power, able to oppose the government represented by oligarchies and commercial interests. Numerous other industries were to follow: cotton, silk, leather, metals, glass, printed paper and transformation industries such as sugar refining. In particular, the establishment of an industry of luxury goods and an art industry seems to be due to their minimum environmental impact on the delicate balance of the city forever linked to the precarious morphology of the Laguna. It was the environment of the city, characterized by strong humidity and the lack of fresh water that damaged some industries, weakening them, as was the case with hides, ${ }^{68}$ during the sixteenth century.

Private and public building construction were of considerable importance, particularly in the sixteenth century when, at least up until the 1576 plague, there was a rapid increase in the population of the city, which boosted the construction of living quarters. Despite its evident importance in terms of labour force, invested capital and for the contribution it made to the port on account of the import of raw materials, it remains an industry that still has to be studied by economic historians, and consequently it is impossible to evaluate its importance to the urban economy. ${ }^{69}$

c. Industry in the Seventeenth and Eighteenth Centuries: The Process of Conversion

The manufacture of high quality woollen cloth mainly intended for foreign markets anchored the choice of products to a market that, for Venetians, was to weaken only in the course of the seventeenth century. ${ }^{70}$ On the mainland a reduction in local sheep breeding resulted in a decrease

${ }^{67}$ Aymard, 'Strategie di cantiere,' 267-273.

${ }^{68}$ Ciriacono, 'Industria e artigianato,' 561.

${ }^{69}$ Sella, 'L'economia,' 676-677.

${ }^{70}$ Sella 'The Rise and Fall of the Venetian Woollen Industry.' On the overall picture of Venetian industries in the seventeenth century see Sella, Commerci $e$ industrie a Venezia. 
in the amount of local high quality wool available, and led to a conversion towards the production of poorer quality cloth mainly worked in rural areas, or even a move towards silk production. The Rialto port, however, continued to benefit from importing good quality wool, mainly from Spain, but also from the Levant and so the wool industry in the capital was only partially affected. On the mainland, the process of reorganization undergone by the productive system favoured the re-launching of the sector above all in rural areas, despite the fact that in the late seventeenth century, it still had to face a negative economic situation. It is significant that, according to Walter Panciera's calculations, ${ }^{71}$ in 1687 the production of high quality Venetian cloth was around $18 \%$ of the state total, while in 1710 the percentage dropped dramatically to around $10 \%$.

The silk industry experienced various vicissitudes. If at first the stagnation of the wool industry encouraged the transfer of investments towards the silk industry, which was able to diversify its production profitably, later on the industry was subject-as it was throughout Italy-to the effects of the reduction in the production of common silk fabric. As a result, it turned to specializing in segments of fabric woven with gold and silver, which were still very much in vogue with the wealthier classes in Europe and in the Ottoman kingdom. ${ }^{72}$ However, it is still not completely clear whether the silk entrepreneurs, as well as obviously the "foreigners" were Venetians or rather belonged to the merchant class of the mainland and so to some degree, the origin of their capital is doubtful. ${ }^{73}$ Certainly the spread in the production of raw material throughout the Venetian state could have favoured the rise of business networks which came from the mainland rather than from Venice. Fresh research is highlighting the industrial system's ability to adapt, whether in Venice or the mainland (at this point, the two areas should be regarded as inextricably linked) when faced with the establishment of a world economy, and the ability to invent fresh products in response to aggressive tactics from new competitors. This could well be the result of the "virtuous" connection between knowledge and the business practices of the Venetians. These skills were part of the know-how acquired during the phase of the city's industrial expansion in the late fifteenth and sixteenth centuries. They can also be attributed to the knowledge of business and commercial practices matured in the more varied commercial world of the subject mainland, which had always included, along with urbanmanufactured goods, products of the proto-industrial activities common to rural areas.

What is certain is that in the seventeenth and eighteenth centuries silk manufacturing still continued to employ large numbers of workers in Venice, including large numbers of women. Documented studies based on censuses show an increase in the number of master weavers from 33 in 1672

\footnotetext{
${ }^{71}$ Panciera, L'arte matrice, 356.

72 Molà, The Silk Industry 299-307; Ciriacono, 'Mass Consumption Goods and Luxury Goods,' 46-47.

73 There has been little research in this area. There are some useful comments in Vianello, 'Mercanti, imprese e commerci nel Cinque e Seicento.'
} 
to 1,218 in $1696,1,206$ in 1712,700 in $1750 .{ }^{74}$ However, a considerable number of these weavers did not own their own workshop or looms and alternated employment in the craft with other activities. By the end of the eighteenth century, men had been replaced by women as the latter were a better source of temporary and flexible labour. ${ }^{75}$ The flexibility and the open-mindedness of the corporations, both the weavers' and the merchants', helped the staying power of the sector. Recent studies show that if they are compared to the French, the prime silk producers in Europe, the Venetian corporations do not seem to have been responsible for hindering technology; in fact, they contributed in a positive way to the introduction of new machinery and new technologies. In professional training they were able to supply innovative solutions that lay outside the scope of traditional instruction in craftsmen's workshops. ${ }^{76}$ Once again, the hostility and the lack of flexibility of corporative structures, one of the most quoted reasons for the Italian decline, has to be reconsidered and should be reinterpreted in the light of the general socio-economic situation at the root of the process of decline. $^{77}$

On the other hand, the resilience of the city's industries was closely related to the importation of raw materials through the port of the Rialto, which Domenico Sella recently highlighted for 1680, surmising that they were utilised by Venetian industries. ${ }^{78}$ Among these materials there was wax, dyes, unrefined sugar, wool (Spanish and Greek-Albanian, the latter probably for the industries of the subject mainland), lead, soda ash, cotton, and leather. As Sella was able to verify, analogous results for Leghorn, Italy's other important port, prove that the whole of northern and central Italy witnessed an industrial vitality that, even though local markets were the favoured outlet for its products, firmly rooted the country in the world economy through the imports of raw materials.

The restructuring of the economic nerve centres in Europe during the sixteenth and seventeenth centuries affected the position of Venice. Like most of the industrial cities and/or the ports of central and northern Italy and the Mediterranean area in general, it became increasingly marginalized. Two factors are, however, worth mentioning: the fact that until its fall the population of Venice was stable and the development of tertiary activity connected to the evolution of the city as a great centre for international tourism. ${ }^{79}$ From the seventeenth century Venice became one of the most popular cities for European tourists, in particular for the French and the English, who made a visit to the city one of the essential highlights of the

${ }^{74}$ Della Valentina, Operai, mezzadi, mercanti, 15.

${ }^{75}$ Della Valentina, Operai, mezzadi, mercanti, 131-138.

${ }^{76}$ Ciriacono, 'Silk Manufacturing in France and Italy in the XVIIIth Century.'

${ }^{77}$ In recent years in Italy the theories on corporations as an element of rigidity and as an obstacle to economic development have been reconsidered: see Guenzi et al., eds., Guilds, Markets and Work Regulations in Italy, parts 1-2. In the case of Venice, the relationships between state and corporations are studied in Mackenney, 'The Guilds of Venice, State and Society,' 34-43.

${ }^{78}$ Sella, 'Industrial Raw Materials,' 65-68.

${ }^{79}$ Tucci, 'Venezia nel Cinquecento: una città industriale?’ 70-71. 
Grand Tour, an educational experience for the elite of that period. However, the history of tourism has so far been studied as an aspect of British and French cultural history, and today we still know little about its impact on the economy of the city. ${ }^{80}$

d. Venetian Industry, Manufactured Goods in the Subject Cities, Proto-Industrial Activities. The Process of Integration in the Response Made by the Venetian Economy to the Structural Changes in Europe

The fact that the subject nobility was not socially integrated with the Venetian elite and the failure to build a wide regional market must both be taken into account if we wish to consider the economic trend of the entire state as well as of Venice itself and the response that the merchant entrepreneurs from the mainland attempted to provide already during the sixteenth century to the changes in the international economic scene and, at the same time, within the Venetian state.

Some of the rich cities of the mainland, in particular those closest to Lombardy, in the centuries prior to their conquest by Venice had acquired the ability to produce a wealth of manufactured goods that placed them, and especially Brescia and Verona, among the great European manufacturing cities of the period. The production of Veronese woollen cloth and the iron goods of Brescia were based in urban centres. The high quality cloths that left the Veronese craftsmen's workshops were destined, as we have pointed out, for the markets beyond the Alps and the Levant. The wool manufacturing sector was also the driving force behind the social mobility of many families who made up the political elite of Verona. The good quality of the Veronese product, as well as that of Vicenza, depended to a large extent on the use of local wool and the breeding of sheep that provided top quality raw material, able to compete with the famous English wool. The demographic situation that was to characterize these urban centres, putting them at the top of the European table, interacted with the felicitous development of the manufacturing sector. The political conquest of these towns had taken place during the fifteenth century, but it was only during the following century that economic domination occurred. This happened mainly in the primary sector and consisted in the massive penetration of Venetian investment in the rural areas of the Veneto, especially in the areas nearest to Venice itself, such as those around Treviso and Padua. This was mainly on account of the difficulty in covering long distances. In fact, it was here that Venetians acquired extensive properties. ${ }^{81}$

Studies in our possession seem to indicate that the mercantile policy of the capital in defence of its own industries at the beginning of the modern era only in part affected the manufacturing policies of the subject cities. In fact, the great changes that were registered in the industrial sector on the mainland in the sixteenth century with the establishment of a world

\footnotetext{
${ }^{80}$ Davis and Marvin, Venice the Tourist Maze, 11-12.

${ }^{81}$ Beltrami, La penetrazione dei veneziani.
} 
economy seem largely to be conditioned by the restructuring of the European economic scene and by the effects of population growth on the primary sector. What most recent studies underscore is that the process of conversion from wool to silk in textile production, carried out by the merchant entrepreneurs operating in the Veneto, was contiguous with the Italian businessmen's conquest of the remaining opportunities in the new world market. The increase in cereal production brought about a reduction in sheep breeding which meant that the high quality wool on which the Venetian wool industry had long been based virtually disappeared. Transhumant pastures continued to be a source of raw material, but it was now of a poorer quality that could not be worked in the urban workshops, controlled by guilds that attached the mark on finished goods before they were sold. As a consequence, this encouraged manufacturing activity in rural areas, which continued to produce low quality cloth for the local market, but also to a certain extent for the markets beyond the Alps, utilizing, if Domenico Sella's assumptions are correct, also wool imported from Greece and Albania.

The conversion of the urban industry to the production of knitted goods and berets, which distinguished Verona and to a lesser extent Padua, was partly an answer to the fact that high quality wool was no longer available, as well as to the increase in demand due to changes in fashion. The massive spread of the cultivation of mulberry bushes and of silk worms throughout the countryside in Central and Northern Italy, and in particular in the Veneto, interacted with a change in fashion and encouraged the conversion of the wool industry to silk, with a production of cloth and either finished or semi-finished silk goods destined for the regional market and for an international market, in particular in continental Europe. As the Venetian senators said, the "use of silk" had become common not only with the aristocracy and the middle classes, but also among more humble classes. This had an effect in Veneto and throughout Europe on the dynamism of the silk industry, which advanced to the detriment of the wool sector. ${ }^{82}$ Silk mills, manual or hydraulic, were rapidly introduced throughout the Veneto, first in the towns, then in various localities in the territory, involving in the different phases of production both the upper classes, like the aristocratic land owners or the merchant entrepreneurs, and the peasant farmers themselves. While the silk industry was mainly situated in towns, the close connection between the city and country was exemplified in towns like Vicenza, characterized by the resilience of its industrial sector and its merchant elite for the whole of the modern age. ${ }^{83}$

It is not surprising, then, from a demographic point of view that after the 1630 plague had wiped out a third of the population of Northern Italy, recovery took place above all in rural areas, swelling the big villages and

\footnotetext{
${ }^{82}$ Relazioni dei rettori veneti in terraferma. Podestaria e Capitanato di Vicenza, report of Zaccaria Mocenigo dated 16th February 1633, 335.

${ }^{83}$ Ciriacono, 'Protoindustria, lavoro a domicilio,' 67-68.
} 
only moderately affecting the towns, ${ }^{84}$ as can be seen in table 2 . The deconstructing of urban industry was an obstacle to recovery in the seventeenth century in the towns of the Veneto, while the more significant population growth in the countryside made it possible for the primary sector to interact with manufacturing. Confirmation of this comes from the increase in the number of fairs in less important centres, above all in areas like that around Vicenza, characterized by a long manufacturing tradition in the villages situated in the pre-alpine belt, like Schio, Valdagno and Thiene, where the revival of the wool industry, already apparent in the late seventeenth century, continued throughout the following century. ${ }^{85}$

However, this situation seemed to have interacted with a different economic scenario in Europe that came into being in the sixteenth and seventeenth centuries and it is the fairs that help to shed light in this direction. They show how Italian merchants in the same period gradually moved towards the east, acquiring market space in the great states in Eastern Europe. ${ }^{86}$ The gatherings at Antwerp and Lyons were gradually replaced in Italian commercial strategy, and by the Veneto merchants themselves, by Frankfurt, Leipzig, Lublin, and Jaroslaw. Italians responded to the gradual marginalizing of western markets by moving their activities towards the east, where they still managed to dominate market quotas, as can be seen in the case of Alessandro Guagnini, a Veronese merchant and nobleman who, in the sixteenth and seventeenth centuries, had commercial dealings with countries that included Poland and Sweden. Here the demand for cloths and silk products intended for the upper classes of these societies, as for the Ottoman market, might have further stimulated in the Italian merchant entrepreneurs a specific interest in silk production, in particular for perhaps more valuable manufactured goods.

After the sixteenth century, demand seemed to undergo a substantial transformation, even though we still know little about the nature of the conditions that made a revolution in consumer goods possible. On this subject, we must accept that long term change was not equally rapid everywhere, without wanting to compare societies subject to change and those that were static. ${ }^{87}$ If in some European regions changes in taste and the consolidation of the idea of fashion privileged the new English draperies and French silks, with a corresponding loss of competitiveness for Italian products, there were still those, probably mainly the upper classes, who continued to express their affection for Italian luxury goods, including those made in the Veneto and Venezia.

\footnotetext{
${ }^{84}$ Fornasin and Zannini, 'Crisi e ricostruzione demografica nel Seicento veneto, 'Lanaro, I mercati nella Repubblica veneta, 79-85. On the small towns see Musgrave, 'The Small Towns of Northern Italy.'

${ }^{85}$ Panciera, 'La formazione delle specializzazioni economiche territoriali,' 253256 and Panciera, 'Qualità e costi di produzione nei lanifici veneti,' which attempts to give an overall picture of wool production in Venice and in Veneto.

${ }^{86}$ Mazzei, Itinera mercatorum, 555-118, Lanaro, 'Introduzione,’ 14-15.

${ }^{87}$ Appadurai, Modernity at Large, chap. 3; Levi, 'Comportements, ressources, procès.'
} 


\section{Aims and Organization of this Collection}

The articles in this collection are the result of recent research in some cases still in progress and up to now only in part published. They seek to provide a comprehensive picture of the role of manufacturing and trade in Venice and on the mainland. Our intention is to present, sometimes in contrast with traditional historiography, the way the economy of the Veneto from the fifteenth to the eighteenth centuries interacted between Venice itself and its subject dominions and to shed fresh light on the Republic and on the new balance of power established in Europe, reassessing interpretations that tediously repeat the myth of the decline of Venice in the modern age.

This has been made possible not only because a variety of documents have been consulted, integrating the archives of the capital with those from the mainland, but also because investigation has begun using new archive sources, such as the documents of the notaries of Venice and the subject cities, including those operating in the countryside. These documents have long been neglected because they are usually difficult to read and interpret.

The first part of this collection is dedicated to Venice as an industrial centre from the fifteenth to the eighteenth centuries and to the study at different times in the history of particular industries located in the city, such as the wool, silk, and glass industries. These studies focus on the duration of the industrial period of Venice.

Three articles open the first part of the collection and deal with the study of the principal Venetian industries of the time. The first is Andrea Mozzato's "The Production of Woollens in the Fifteenth and Sixteenth Centuries.” For the first time wool manufacturing in medieval Venice is examined, a subject which, unlike wool manufacturing in Tuscany and Lombardy, has always been given scant attention because of the way the topic of industry in the Middle Ages was dealt with by Gino Luzzatto and Roberto Cessi. These important historians emphasised the fact that Venice's maritime orientation during the Middle Ages had been an obstacle to the development of the manufacturing sector, with the exception of ship building. The privileges granted to maritime trade contributed to the weakness of the wool industry. Its revival in the modern era was the result of the decline in maritime trade which favoured the advance of the industrial sector. Andrea Mozzato, on the contrary, suggests that the fifteenth-century commercial potentialities did not curb the sector, which was able to take off successfully in the following century, thanks to the working structures that were already in place in the sector in the Middle Ages. The abundance on the Rialto market of raw material from various sources, English, Greek, French, Spanish, Levantine, as well as from the Veneto, enabled Venetian wool manufacturers to produce different types of cloth according to demand. Sources are not available, so it is not possible to quantify details of production in the late medieval period, unlike in the early modern age. The sources studied suggest that in the fifteenth century at least between 7,000 and 9,000 bales of cloth were made. It can be assumed that at the end of the 
century between 6 and 7,000 men were employed in this sector, almost all of them "foreigners"; in this sense the wool industry could be said to be multi-ethnic. What in Florence were two distinct guilds, the Wool Guild and the Calimala (a parallel wool guild), in Venice were joined in one corporation, the Wool Guild, subject to legislation on the part of the aristocracy, who invariably attempted to coordinate local production with the trade of foreign cloth by alternating throughout the fourteenth and fifteenth centuries protectionist practice and free trade. The intermittent largesse/restriction was abandoned when, halfway through the fifteenth century, it was decided that, to facilitate a place for Venetian cloth on the market, production should be diversified and backed by protectionist measures. By producing top quality cloth designed for wealthy buyers and low or medium quality cloth for export, Venice successfully reacted to the weakening of the Levantine market, to an increase in wealth in Western Europe, and to the success of the proto-industry in smaller towns in the state. Similar policies were adopted to encourage diversification in the silk industry, the other key textile sector in Venice, whose manufactured goods included valuable damasks and brocades as well as other textiles made with a mixture of silk and other fibres. This sector expanded throughout the sixteenth century up until the 1630-31 plague thanks to the attention given to the market and to technological innovation. The crisis following the plague was not as great as the one that hit the wool industry. In fact, in the last three decades of the seventeenth century the Venetian textile industry reached its peak, at least in quantitative terms.

Marcello Della Valentina's “The Silk Industry of Venice: Guild and Labour Relations in the Seventeenth and Eighteenth Centuries” deals with this phase. Faced with increased imports of silk from Lyons, Venice successfully entered a new phase whose aim was to try and find a niche on the international silk market and to reorganize production and labour. Alongside the new commercial strategies, flexibility in work and in the increasing use of cheap female labour were the fundamental features that enabled Venetian manufacturing to resist and to continue to be one of the main economic activities of the city throughout the eighteenth century. Its commercial strategies have for some time been quite clear: Venice managed to maintain its position by producing luxury goods designed to satisfy the demand from the Levant, which had hardly been penetrated by cloth from Lyons, but where la Serenissima had long enjoyed a reputation for fabrics and had an established a network of commercial contacts. Furthermore, Venice copied the Lyons fabrics in order to counteract the spread of French products in the flourishing internal market. Even though these commercial decisions were important, the actual staying power of the silk industry seems to have depended more on the flexibility of its artisans and its corporative institutions and on changes in employment structures which increasingly resorted to female workers. Women employed in weaving were usually exploited and not safeguarded by traditional guild protection. Men's wages depended on the amount of work they did, but women were given a paltry weekly wage, entirely to the advantage of the capimaestro. It was the control of production costs through low-paid women workers that kept the 
Venetian silk industry competitive. Thousands of women laboured alongside male weavers, without however, benefiting from any protection from the Venetian guild system. Clearly, then, the guilds failed to guarantee the interests of all the workers in this sector. The endurance of the Venetian silk industry in the last 130 years of the history of the Republic must be interpreted in light of the substantially subordinate position of Venetian factories, which felt the need to follow trends and fashions started elsewhere. What was missing was the ability to innovate as far as technology and fashion were concerned.

In "Murano Glass, Continuity and Transformation (1400-1800)" Francesca Trivellato examines a sector, the production of glass, where Venice, in the fifteenth century, was the leading manufacturer thanks to its technical superiority and to the use of first class raw materials. Its primacy was challenged by the innovations introduced in England, Bohemia, and France during the last decades of the seventeenth century. Historiography has traditionally put the blame for the decline of Venetian glass on these countries' new techniques. The decline in this sector was seen as one of the symbols, though not the only one, of the decline in the Venetian economy as a whole and of its transformation from centre of production to centre of distribution and consumption. In fact, the crisis in the Venetian economy seems to have been exaggerated, for it was the glass sector which contributed to bolstering exports in the centuries of "relative decline." It was in the second half of the eighteenth century that the sector expanded, doubling the sales reached two centuries previously. This was due to changes made to the product and to the creation of a diversified market. The glass sector responded to international competition by decreasing the production of top quality cut glass and increasing the production of small mirrors, but concentrating principally on the production of glass beads intended for the colonial market. This was Venice's part in the slave trade, in the exchange of goods happily used by the slave traders. ${ }^{86}$ In other words, the Venetian guilds responded to competition by specialising their products. ${ }^{87}$ In the late seventeenth century the glass industry changed from a luxury industry to the production of cheaper and widely used goods for export. If this allowed manufacturers and Venetian merchants to capture significant market niches, it also meant a growing dependency on foreign intermediaries, especially for access to colonial outlets.

Walter Panciera's article "Venetian Industries in the Seventeenth and Eighteenth Centuries" closes this first part on Venice and discusses the climate of uncertainty and instability that, in the seventeenth and eighteenth centuries, hung over the manufacturing sector of the capital. He attributes the decline in Venice's prosperity and the loss of the Republic's exclusive role as a link between the Eastern Mediterranean and the centre-north of Europe to the economic crisis that affected the entire continental Europe in the 1620s, on the war that was tearing apart Persia and Europe at that time, and on the devastating plague of 1630 . The decline of the city and the

\footnotetext{
${ }^{86}$ Trivellato, 'Tra innovazione e conservazione,' 5-6.

${ }^{87}$ Trivellato, Fondamenta dei vetrai, 111-127.
} 
demographic stagnation that followed - between 1670 and the end of the century when Venice's inhabitants numbered between 130,000 and 140,000 - lead us to reflect on an apparent contradiction: throughout the whole of the ancien régime, Venice remained a great city and a great industrial centre, while at the same time, in comparison with the great capitals of Europe, its relative influence decreased considerably. What Venice experienced was not then a dramatic de-industrialization; in fact, Richard Rapp's traditional theory of its relative decline does not seem to take into account the urban problems related to product flexibility and innovation, to the ability of the industrial system to transform itself, and to its ability to respond to the aggression of new and dangerous competitors. It was the physical and human resources accumulated by some sectors of Venetian industry and the technological and commercial know-how, acquired in the fifteenth and sixteenth centuries, that made it possible to react positively to the changes brought about by the creation of a world economy that affected Europe at that time.

The slump in the wool industry was balanced by other sectors like silk, glass and books. Restructured, and/or on a new footing, they were able to sustain and in some cases re-launch the industrial sector in Venice in the seventeenth and eighteenth centuries. Generally speaking, scant attention was paid to the mechanization of the production process, unlike in England where the more advanced industries were already mechanized. Rather than the entrepreneurs' inability or reluctance to update, this was due to an abundant supply of labour in the capital that did not bring pressure for technological innovation.

The second part of this collection deals with the study of manufacturing in the Veneto State, examining both urban manufacturing and the proto-industry, which was spreading in rural areas. As for the countryside, the area of Venetian-Lombardy, in particular, makes it possible to analyse some of the forms of centralized industry, mainly connected with metal-working. It is thus possible to trace from the Late Middle Ages to the Modern Era both the development of the centralized and the putting-out system in towns and rural areas. ${ }^{88}$ The analysis along these lines covers the whole of the mainland including the areas at the far west of the state (Brescia, Crema, and Bergamo), which are generally neglected in research into the late medieval period.

Edoardo Demo's article “The Textile Industry in the Venetian Mainland" opens this section. In it he concentrates on the textile industry in the Late Middle Ages and Early Modern Era in the Veneto, an area well known already in the fifteenth and sixteenth centuries not merely for its vigorous urban production of medium to high quality goods, but also for a widespread production of wool and silk in numerous "less important centres." The author identifies the ample availability of good quality local wool as one of the principal factors in the development of the wool industry. While the main Italian centres producing woollen cloth, such as Florence and Milan, were obliged to use foreign raw material, for the local wool was

\footnotetext{
${ }^{88}$ Colli, 'L’attività siderurgica,’ 179-199.
} 
of an inferior quality, in the Veneto area in the fourteenth and fifteenth centuries the quality of sheep breeding improved considerably. So much so that the production of good quality cloth was almost completely freed from the need to obtain supplies of foreign raw material. The careful selection of raw materials facilitated the spread, in the main urban centres, of the production of woollen textiles designed for export to Central and Southern Italy, the German area, Central-Continental Europe and the Levant. However, the production of high quality wool was not confined to towns: in the fifteenth and sixteenth centuries wool production spread to many rural areas, especially in the foothills, where there was an abundance of raw material, water power, and wood. Here, it was mediocre goods that were produced with inferior "local" wools or with lower quality imported wools, and even with rejects from the different phases of production, but not, however, designed exclusively for the local market. In the late seventeenth century, large villages like Schio and Valdagno, managed to find opportunities for expansion to the extent that they were able to set up rudimentary sites for specialized production that still can be counted among the major European centres of wool production. Alongside wool manufacturing, the silk industry began to flourish and already at the end of the fifteenth century it proved to be the main source of income. In this case, however, the spread of silk production did not mean the production of silk fabrics, which was insignificant until the seventeenth century, but the development of spinning that led to the construction of manual or waterpowered plants for the production of different types of semi-worked goods of different qualities, commercialised especially by Verona and Vicenza, anticipating a trend that from the mid-seventeenth century would become a typical feature of the silk industry in Northern Italy. Sophisticated mercantile networks were organized on an international scale to distribute these goods. In the sixteenth and seventeenth centuries merchants and entrepreneurs from mainland Veneto were among the active operators in the sector in France, in Germany, in England and in Holland. ${ }^{89}$

Wool production on the mainland went through an extremely critical phase towards the end of the sixteenth century. The wool mills managed partly to recover from this crisis, diverting their investments from the production of cloth to the production of berets, stockings, and other knitted goods. In the last sector Marco Belfanti's "Fashion and Innovation in Light Textile Manufacturing in the Venetian State (Sixteenth to Eighteenth Centuries)" reconstructs the history of the spread of knitted goods, chiefly the production of hand-knitted wool stockings in the sixteenth and seventeenth centuries, singling out Verona and Padua as leaders in production, at least until the end of the seventeenth century. Production was based on an urban putting-out system, on which the manufacturing of hosiery depended up until the eighteenth century when the knitting loom for making silk hosiery, invented by the Englishman William Lee, was introduced on the Continent. The loom radically transformed the production of knitted goods, affecting the costs and the quality of the product. In Padua

${ }^{89}$ Demo, 'Sete e mercanti vicentini.' 
the attempt to introduce the loom was a failure on account of the established system of low cost labour and the strong opposition of both the wool guilds and the city council. In Venice itself the loom for silk stockings was widely used. As elsewhere in Europe, it proved extremely convenient to use the loom where a specialized system for processing silk was already in existence-in other words, where there was well-established technical know-how, easy access to the market in raw materials, and a knowledge of market outlets. The Venetian government granted long-term monopolies to those who wished to use English technology for the manufacture of hosiery. A guild of hosiers was established, but throughout the eighteenth century the Venetian market continued to be swamped by foreign goods. The policy of granting privileges to the Venetian factories must have been ineffective, for in the end the same rights were also granted to the subject cities. In spite of these efforts to boost Venetian hosiery, difficulties did not diminish and the goods continued to lose their competitiveness.

However, there was one sector which in the seventeenth and eighteenth centuries enjoyed good fortune: the ceramics industry. Giovanni Favero's contribution, “Old and New Ceramics: Manufacturers, Products and Markets in the Venetian Republic in the Seventeenth and Eighteenth Centuries" gives an account of this industry. Once the production of ceramics and terra cotta in Venice and Padua came to an end in the second half of the seventeenth century, the centre for the production of ceramics moved to the foothills around Vicenza, to the factories of Bassano, Angarano, and Nove, where it was easier to obtain supplies of raw materials and to exploit important trade routes. ${ }^{90}$ Individual factories spawned other centres of production, which leads us to conclude that Venice's policy of granting privileges proved to be a flexible means of defending innovation. This was in no way an obstacle to the spread of factories, but encouraged the emergence of factories also in the capital, thanks to the good offices of some of the aristocracy. In the eighteenth century privileges granted to manufacturers enabled them to stave off competition from new foreign goods sold on the home market, but it is evident that they were also able to penetrate foreign markets along the routes towards the centre-north of Italy, central Europe and the Mediterranean. The imitation of foreign fashions and new ceramic materials that became popular during the century could be mistaken for real artistic and technical innovations, adopted in an effort to respond to the needs of a market that was particularly sensitive to fashion and foreign novelties, often known only indirectly. Once again, the role of the workers and artisans who moved from one factory to another acquiring and transmitting valuable know-how was crucial. The study of lengthy court cases brought by the manufacturers against their workers helps us understand the link that united different factories in a system that included both subjective competition and objective co-operation that extended on a regional scale with offshoots in the states of the Po Valley and in Lombardy. The case of the production of ceramics differs from other light industries,

${ }^{90}$ From an artistic point of view see Ericani and Marini eds, La ceramica nel Veneto, 275-415. 
such as textiles, in so far as the cost of setting up production was colossal and required the entrepreneurs to be able to release capital from other sources. These privileged ceramic makers sometimes came from the mercantile class, who had accumulated capital from the production and commerce of silk, or even from the governing aristocracy, who managed to obtain from the magistracy donations normally denied to petitioners.

Two articles on territorial specialisations from the sixteenth to the eighteenth centuries complete the book. The authors' aim is to examine how and when the productive regional structure, which already in the Renaissance appears to be divided geographically according to different orientations, responded to market demands by reorganizing production, with further specializations in specific areas. The results can not be easily understood if analysed along the model of an integrated region; however, they become more comprehensible if linked to district economies open to commerce and to the entire production process both within and outside the state.

It is in this light that Luca Mocarelli approaches the study of production specializations and the study of the formation of a regional market in Venetian Lombardy in the seventeenth and eighteenth centuries in his "Manufacturing Activities in Venetian Lombardy: Production Specialization and the Making of a Regional Market.” The morphology of the Lombard territory in fact encouraged the establishment of a diversified economy, beginning with agriculture, marked by a clear productive division, where some important towns like Milan, Bergamo, and Brescia acted as a link between the plains and the mountain area. The geographically central position of the Lombard area, a frontier between the Alps and the Po Valley, already had been strengthened already in the Middle Ages by important investments in infrastructure, like the construction of navigable canals able to connect the Lombard area to the Po and to the Adriatic. In spite of the political boundaries, these investments encouraged an internal cohesion of the territory and the creation of large markets, where the Bergamo Fair of Saint Alexander played a cohesive role that considerably furthered trade links with the State of Milan. The marginal political position of the area (both the cities of the Veneto with regards to Venice, and Milan with regards to Spain) must have contributed to maintaining an important urban framework that generated a sizeable internal demand and assured the persistence of specialized and diversified manufacturing activities. Thus, in the Lombard area there was a cumulative process that placed Lombardy in the same position as those regional economies that were able to exploit the benefits of an initial superiority due to their history. The growth that resulted created fertile conditions that enabled business skills to develop that were to be crucial to industrialization in the nineteenth century. In this light the importance of manufacturing activity, a sector in which Venetian Lombardy played a key role, and the marketing of the goods produced was by no means negligible.

Francesco Vianello studies the same process of specialization, but in the Veneto region and in the area around Vicenza. In his article "Rural Manufactures and Patterns of Economic Specialization: Cases from the 
Venetian Mainland," he highlights the way in which production of manufactured goods for the rural market became of economic importance in the fourteenth and fifteenth centuries. However, it is only towards the end of this period that a system of territorial specializations, which were to last almost to the present day, became stabilized and saw the concentration of rural goods in the pre-alpine belt. Although there are occasions when the wool guilds of Vicenza were in conflict with the rural manufacturers, the growth of wool mills in the countryside followed a logical system of integration which allowed the city to produce better quality goods and the villages of the foothills to make everyday goods. The decline in the production of wool in the Vicenza area at the end of the sixteenth century opens a new phase characterized by a process of specialization that this time involved areas other than the pre-alpine belt. If the western part of the region remained faithful to wool production, the eastern parts changed to new product specializations, to straw and ceramics, but principally to silk. The establishment of a system with specialization on a regional scale was limited by the slow or even the absent development in agriculture curbed by farms were there was little specialization, preventing the primary sector from fully realizing its productive potential.

The studies published are a rich example of dynamic research and the new methodological approach to a subject like manufacturing that only now has begun to disclose its complexity. What still remains to be clarified is, on the one hand, the relationship between agriculture and/or agrarian contracts and on the other, the spread of proto-industrial activities in rural areas. Well established theories place the spread of proto-industrial activity in pre-alpine areas. This was true not only in the area of the Veneto, but also in the Lombard area on account of the presence there of running water, of the ease with which contacts with markets beyond the Alps were maintained, and principally on account of the spread of smallholdings that could not provide a farmers' family with a living merely from agriculture. These theories, however, have recently been questioned by research that has shed light on the penetration of proto-industrial activity anchored to the putting-out system also in areas of the plains, like the southern part of the Po Valley with its huge estates and the figure of the tenant farmer and the salaried worker. ${ }^{91}$ Once again, a wealth of studies in different fields which deal with different historical periods seems to be the answer to theoretical interpretations that remain too firmly linked to static sequences and are unsatisfactory from a methodological and historiographic point of view.

The other point yet to be clarified concerns the question of credit and the financing of industrial and commercial activities. It is still not completely clear how entrepreneurs from the Veneto (but not only them) financed their businesses: self-financing, the use of letters of credit, the practice of some form of loan are only some of the possible means used.

\footnotetext{
${ }^{91}$ Caracausi, Nastri, nastrini, cordelle, 79-97.
} 
There is, though, much work still to be done, and much still needs to be done at a European level. ${ }^{92}$

Università di Venezia Ca’ Foscari

Translated by: Christine Calvert

\section{Tables}

Table 1.

Cities with more than 15,000 inhabitants in 1300 (Centre and North) (in 1000s).

\begin{tabular}{|c|c|c|c|c|c|}
\hline Milan & 150 & Pisa & 30 & Fano & 20 \\
\hline Venice & 110 & Mantua & 30 & Modena & 19 \\
\hline Florence & 110 & Parma & 25 & Fermo & 19 \\
\hline Genoa & 60 & Lucca & 25 & Arezzo & 18 \\
\hline Bologna & 50 & Perugia & 25 & Gubbio & 18 \\
\hline Siena & 50 & Ancona & 25 & Recanati & 17 \\
\hline Brescia & 45 & Ascoli Piceno & 25 & Spoleto & 17 \\
\hline Cremona & 45 & Piacenza & 23 & Alessandria & 16 \\
\hline Padua & 40 & Pavia & 20 & Orvieto & 16 \\
\hline Verona & 40 & Vicenza & 20 & \begin{tabular}{|l} 
Treviso \\
\end{tabular} & 15 \\
\hline
\end{tabular}

Source: Malanima, Italian Cities 1300-1800: A quantitative approach, 118.

Table 2.

\footnotetext{
${ }^{92}$ For a comment on the situation in Italy see Boschiero and Molina, ed., Politiche del credito, 141-221.
} 
Population of the Venetian State.

\begin{tabular}{|c|c|c|}
\hline & 1548 & 1766 \\
\hline Venice & 157.877 (1555) & 140.516 \\
\hline Udine & 14.579 & 14.399 \\
\hline country side & 180.463 & 302.999 \\
\hline Belluno & 4.168 & 3.968 \\
\hline country side & 19.657 & 44.644 \\
\hline Feltre & 3844 & 4071 \\
\hline country side & 21.835 & 27.453 \\
\hline Treviso & 11798 & 9997 \\
\hline country side & 145.368 & 269.617 \\
\hline Padova & 34.075 & 40.795 \\
\hline country side & 116.075 & 234.511 \\
\hline Rovigo & 2.473 & 5.355 \\
\hline country side & 26.353 & 68.316 \\
\hline Vicenza & 30.948 & 28.289 \\
\hline country side & 124.760 & 184.566 \\
\hline Verona & 52.109 & 51.693 \\
\hline country side & 118.728 & 181.800 \\
\hline Brescia & 42.660 & 38.889 \\
\hline country side & 300.413 & 276.272 \\
\hline Bergamo & 17.707 & 25.581 \\
\hline country side & 104.804 & 168.218 \\
\hline Crema & 10.689 & 8.600 \\
\hline country side & 18.443 & 30.841 \\
\hline
\end{tabular}

Sources: Fornasin - Zannini, Crisi e ricostruzione demografica nel Seicento Veneto, 115-116 (elaboration from data in Beloch, La popolazione d'Italia nei secoli XVI, XVII e XVIII). 


\section{Works Cited}

Appadurai, Arjun. Modernity at Large: Cultural Dimensions of

Globalization. Minneapolis and London: University of Minnesota Press, 1996.

Aymard, Maurice. 'Strategie di cantiere' pp. 259-283 in Storia di Venezia. Il Mare, eds. Alberto Tenenti and Ugo Tucci. Rome: Istituto dell'Enciclopedia Italiana, 1991.

Belfanti, Carlo Marco. 'Maglie e calze’ pp. 583-625 in Storia d'Italia. Annali 19 La moda, eds. Carlo Marco Belfanti and Fabio Giusberti. Turin: Einaudi, 2003.

Belfanti, Carlo Marco. 'Guilds, Patents, and the Circulation of Technical Knowledge. Northern Italy during the Early Modern Age.' Technology and Culture, 45:3 (2004): 569-589.

Beloch, Julius. La popolazione d'Italia nei secoli XVI, XVII e XVIII, Rome: Botta, 1888.

Beltrami, Daniele. La penetrazione economica dei veneziani in terraferma. Forze di lavoro e proprietà fondiaria nelle campagne venete nei secoli XVII e XVIII. Venice and Rome: Fondazione Giorgio Cini - Istituto per la Collaborazione Culturale, 1961.

Benetti, Sante. L'accorto fattor di villa, ed. Danilo Zanlorenzi. Martellago: s.e., 2001.

Berengo, Marino. L'agricoltura veneta dalla caduta della Repubblica all’Unità. Milan: Banca Commerciale Italiana, 1963.

Berveglieri, Roberto. 'Cosmo Scatini e il nero di Venezia.' Quaderni Storici, 18:52 (1983): 167-79.

Borelli, Giorgio. 'Terra e patrizi nel XVI secolo: Marcantonio Serego.' Studi Storici Veronesi Luigi Simeoni, 26-27 (1976-1977): 43-73.

Boschiero, Gemma and Barbara Molina, eds., Politiche del credito investimento consumo solidarietà. Asti: Arti Grafiche TSG, 2004.

Braudel, Fernand. Civilisation matérielle, économie et capitalisme, XVeXVIIIe siècle. Paris: Armand Colin, 1979, 3 vols.

Caizzi, Bruno. Industria e commercio della Repubblica Veneta nel XVIII secolo. Milan: Banca Commerciale Italiana, 1965.

Caracausi, Andrea. Nastri, nastrini, cordelle: L'industria serica nel Padovano secc. XVII-XIX. Padua: Cleup, 2004.

Cipolla, Carlo Maria. 'The Economic Decline of Italy’ pp. 126-145 in Crisis and Change in the Venetian Economy, ed. Brian Pullan. London: Methuen, 1968.

Ciriacono, Salvatore. 'Silk manufacture in France and Italy in the XVIIth Century: Two Models Compared.' The Journal of European Economic History, 10:1 (1981): 167-199.

Ciriacono, Salvatore. 'Protoindustria, lavoro a domicilio e sviluppo economico nelle campagne venete.' Quaderni Storici, n.s., 52 (1983): 5780.

Ciriacono, Salvatore. 'Mass Consumption Goods and Luxury Goods: The De-Industrialization of the Republic of Venice from the Sixteenth to the 
Eighteenth Century' pp. 41-119 in The Rise and Decline of Urban Industries in Italy and in the Low Countries, ed. Herman Van der Wee. Leuven: Leuven University Press, 1988.

Ciriacono, Salvatore. 'Industria e artigianato” pp. 523-592 in Storia di Venezia. Dalle origini alla caduta della Serenissima, vol. 5: Il Rinascimento. Società ed economia. Rome: Istituto dell'Enciclopedia Italiana, 1996.

Colli, Andrea. 'L'attività siderurgica nel territorio bergamasco in età moderna' pp. 179-215 in Storia economica e sociale di Bergamo: Il tempo della Serenissima. Un Seicento in controtendenza, eds. Aldo De Maddalena et al. Bergamo: Fondazione per la storia economica e sociale di Bergamo, 2000.

Cozzi, Gaetano. 'Ambiente veneziano, ambiente veneto. Governanti e governati nel dominio di qua dal Mincio nei secoli XV-XVIII' pp. 291352 in Gaetano Cozzi, Ambiente veneziano, ambiente veneto. Saggi su politica, società cultura nella Repubblica di Venezia in età moderna. Venice: Marsilio, 1997.

Cozzi, Gaetano and Michael Knapton. La Repubblica di Venezia nell'età moderna: Dalla guerra di Chioggia al 1517. Turin: UTET, 1986.

Davis, Robert. Shipbuilders of the Venetian Arsenal. Workers and Workplace in the Preindustrial City. Baltimore: The Johns Hopkins University Press, 1991.

Davis, Robert and Garry R. Marvin. Venice The Tourist Maze: A Cultural Critique of the World's Most Touristed City. Berkeley, Los Angeles, London: University of California Press, 2004.

Della Valentina, Marcello. 'I mestieri del pane a Venezia tra '600 e '700.' Atti dell'Istituto Veneto di Scienze, Lettere e Arti, 150 (1991-92): 113216.

Della Valentina, Marcello. Operai, mezzadi, mercanti: Tessitori e industria della seta a Venezia tra '600 e '700. Padua: Cleup, 2003.

Demo, Edoardo, $L$ ' “anima della città." L'industria tessile a Verona e Vicenza (1400-1550). Milan: Unicopli, 2001

Demo, Edoardo. 'Sete e mercanti vicentini alle fiere di lione nel XVI secolo’ pp. 177-199 in La pratica dello scambio: Sistemi di fiere, mercanti e città in Europa (1400-1700), ed. Paola Lanaro. Venice: Marsilio, 2003.

Demo, Edoardo. 'Le manifatture tra medioevo ed età moderna' pp. 21-126 in L'industria vicentina dal Medioevo a oggi, ed. Giovanni Luigi Fontana. Padua: Cleup, 2004.

Demo, Edoardo. “"Da Bressa se traze panni fini e altre sorte de panni de manco precio”. L'esportazione dei prodotti tessili bresciani nel '400.' Annali Queriniani, 5-6 (2005): 101-130.

De Vries, Ian. European Urbanization 1500-1800. London: Methuen \& Co., 1984.

Epstein, Stephan R. 'Strutture di mercato’ pp. 73-134 in Lo stato territoriale fiorentino (secoli $X I V-X V$ ). Ricerche, linguaggi, confronti, ed. Andrea Zorzi and William J. Connell, Pisa: Pacini, 2001. 
Epstein, Stephan R. Freedom and Growth. The Rise of states and Markets in Europe, 1300-1750. London and New York: Routledge, 2000.

Epstein, Stephan R. The Generation and Transmission of Technical Knowledge in Pre-Modern Europe, C.1200-C.1800, (Working Paper in the Nature of Evidence: How well do facts travel? 2005/1).

Ericani, Giuliana and Paola Marini, eds., La ceramica nel Veneto. La Terraferma dal XIII al XVIII secolo. Verona: Banca Popolare di Verona, 1990.

Fornasin Alessio and Andrea Zannini. 'Crisi e ricostruzione demografica nel Seicento veneto’ pp. 103-122 in La popolazione italiana nel Seicento, ed. SIDES. Bologna: Clueb, 1999.

Favero, Giovanni, Maria Moro, Pierpaolo Spinelli, Francesca Trivellato and Francesco Vianello. 'Le anime dei demografi. Fonti per la rilevazione dello stato della popolazione di Venezia nei secoli XVI e XVII.' Bollettino di demografia storica, 15 (1991): 23-110.

Galli della Loggia, Ernesto. L'identità italiana. Bologna: il Mulino, 1998.

Genet, J. Philippe. 'La genèse de l'état moderne. Les enjeux d'un programme de recherche.' Actes de la recherche en Sciences Sociales, 118 (1997): 3-18.

Ginatempo, Maria and Lucia Sandri. L'Italia delle città. Il popolamento urbano tra Medioevo e Rinascimento (secoli XIII-XVI). Florence: Le Lettere, 1990.

Grenier, Jean-Yves, L'économie d'Ancien Régime. Un monde de l'échange et de l'incertitude. Paris: Albin Michel, 1996.

Guenzi, Alberto, Paola Massa and Fausto Piola Caselli, eds. Guilds, Markets and Work Regulations in Italy, 16th-19th centuries. Aldershot: Ashgate, 1998.

Gullino, Giuseppe. 'Quando il mercante costruì la villa: le proprietà dei Veneziani nella terraferma’ pp. 875-924 in Storia di Venezia, vol. 6: Dal Rinascimento al Barocco. Rome: Enciclopedia Italiana, 1994.

Knapton, Michael. ' "Nobiltà e popolo” e un trentennio di storiografia veneta.' Nuova Rivista Storica, 82:1 (1998): 167-192.

Knapton, Michael. 'Venezia tra apogeo e declino' pp. 109-149 in Storia del Veneto, vol. 1: Dalle origini al Seicento, ed. C. Fumian and A. Ventura, Rome and Bari: Laterza, 2004.

Knapton, Michael. 'La Terraferma' pp. 165-182 in Storia del Veneto, vol. 1: Dalle origini al Seicento, ed. C. Fumian and A. Ventura, Rome and Bari: Laterza, 2004.

Grubb, James. 'When Myths Lose Power: Four Decades of Venetian Historiography.' The Journal of Modern History, 68:1 (1986): 41-94.

Jones, Philip. 'Economia e società nell'Italia medievale: la leggenda della borghesia' pp. 185-372 in Storia d'Italia - Annali, vol. 1: Dal feudalesimo al capitalismo. Turin: Einaudi, 1978.

Lanaro, Paola. " "Essere famiglia di consiglio": Social Closure and Economic Change in the Veronese Patriciate of the Sixteenth Century.' Renaissance Studies, 8:4 (1994): 428-438. 
Lanaro, Paola. 'I rapporti commerciali tra Verona e la Marca anconetana tra basso medioevo ed età moderna.' Studi Storici Luigi Simeoni, 45 (1995): 9-25.

Lanaro, Paola. 'Economia cittadina, flussi migratori e spazio urbano in Terraferma veneta tra basso medioevo ed età moderna' pp. 63-81 in La città italiana e i luoghi degli stranieri XIV-XVIII secolo, eds. Donatella Calabi and Paola Lanaro. Rome and Bari: Laterza 1998.

Lanaro, Paola. 'Introduction’ pp. 155-158 in Les étrangers dans la ville, eds. Jacques Bottin and Donatella Calabi. Paris: Editions de la Maison des sciences de l'homme, 1999.

Lanaro, Paola. 'Economic Space and Urban Policies. Fairs and Markets in the Italy of the Early Modern Age.’ Journal of Urban History, 30:1 (2003): 37-49.

Lanaro, Paola. 'Introduzione' pp. 9-17 in La pratica dello scambio: Sistemi di fiere, mercanti e città in Europa (1400-1700), ed. Paola Lanaro. Venice: Marsilio, 2003.

Lanaro, Paola. 'Periferie senza centro. Reti fieristiche nello spazio geografico della terraferma veneta in età moderna” pp. 21-51 in La pratica dello scambio: Sistemi di fiere, mercanti e città in Europa (14001700), ed. Paola Lanaro. Venice: Marsilio, 2003.

Lanaro, Paola. 'Il contesto economico e territoriale nei secoli XV-XVIII' pp. 148-153 in Andrea Palladio e la villa veneta da Petrarca a Carlo Scarpa, eds. Guido Beltramini and Howard Burns. Venice: Marsilio, 2005.

Lanaro, Paola, Un'oligarchia urbana nel Cinquecento veneto. Istituzioni, economia società. Turin: Giappichelli, 1992.

Lanaro, Paola, I mercati nella Repubblica Veneta. Economie cittadine e stato territoriale (secoli XV-XVIII). Venice: Marsilio, 1999.

Varanini, Gianmaria and Paola Lanaro. 'Egemonia sul territorio e reti di relazioni nella storia di Verona medievale e moderna (secoli XII-XVIII)' pp. 33-68 in Una rete di città. Verona e l'area metropolitana AdigeGarda, ed. Maurizio Carbognin, Eugenio Turri and Gian Maria Varanini. Verona: Cierre, 2204.

Lane, Frederic C. Venetian Ships and Shipbuilders of the Renaissance. Baltimore: The Johns Hopkins University Press, 1944.

Lane, Frederic C. Andrea Barbarigo, Merchant of Venice. Baltimore: The Johns Hopkins University Press, 1944.

Lane, Frederic C. Venice A Marittime Republic. Baltimore: The Johns Hopkins University Press, 1973.

Levi, Giovanni. Centro e periferia di uno stato assoluto. Tre saggi su Piemonte e Liguria in età moderna, Turin: Rosenberg \& Sellier, 1985

Levi, Giovanni. 'The Origins of the Modern State and the Microhistorical Perspective' pp. 53-82 in Mikrogeschichte Makrogeschichte Komplementar oder Inkommernsurabel, ed. Jürgen Schlumbohm, Gottingen: Max Planck-Institut für Geschichte, 1998.

Levi, Giovanni. 'Comportements, ressources, procès: avant la "révolution" de la consommation’ pp. 187-207 in Jeux d'échelles: La micro-analyse à l'expérience, ed. Jacques Revel. Paris: Gallimard-Le Seuil, 1996. 
Luzzatto, Gino. 'Les activités économiques du Patriciat vénitien (Xe-XIVe siècles)” pp. 125-165 in Gino Luzzatto, Studi di storia economica veneziana. Padua: Cedam, 1954 (orig. ed. 1937).

Luzzatto, Gino. Storia economica di Venezia dall'XI al XVI secolo. Venice: Marsilio, 1995 (orig. ed. 1961).

Luzzatto, Gino. Per una storia economica d'Italia, Rome and Bari: Laterza, 1967.

Mackenney, Richard. Tradesmen and Traders. The World of the Guilds in Venice and Europe, c. 1250-c.1650. London and Sydney: Croom Helm, 1987.

Malanima, Paolo. 'Politica ed economia nella formazione dello stato regionale: il caso toscano.’ Studi Veneziani, n.s. 11 (1986): 61-72.

Malanima, Paolo, La fine del primato. Crisi e riconversione nell'Italia del Seicento. Milan: Bruno Mondadori, 1998.

Malanima, Paolo. 'Italian Cities 1300-1800. A Quantitative Approach.' Rivista di Storia Economica, 14:2 (1998): 91-126.

Martin, John ad Dennis Romano. 'Reconsidering Venice’ pp.1-35 in Venice Reconsidered, eds. John Martin and Dennis Romano. Baltimore: Johns Hopkins University Press, 2000.

Mazzei, Rita. Itinera mercatorum: Circolazione di uomini e beni nell'Europa centro-orientale 1550-1650. Lucca: Maria Pacini Fazzi, 1999.

Mocarelli, Luca. 'Alla periferia di una economia regionale. Il Bresciano tra Sei e Settecento’ pp. 138-152 in Regional Development and Commercial Infrastructure in the Alps: Fifteenth to Eighteenth Centuries, ed. U. Pfister, Basle: Schwabe, 2002.

Mocarelli, Luca. 'L'economia bergamasca tra conferme e nuovi sviluppi' pp. 267-294 in Bergamo e il suo territorio. Milan: Cariplo, 1997.

Molà, Luca. La comunità dei Lucchesi a Venezia. Immigrazione e industria della seta nel tardo Medioevo. Venice: Istituto Veneto di Scienze, Lettere e Arti, 1994.

Molà, Luca. The Silk Industry of Renaissance Venice. Baltimore and London: The Johns Hopkins University Press, 2000.

Moroni, Marco. 'Mercanti e fiere tra le due sponde dell'Adriatico nel Basso Medioevo e in Età Moderna' pp.53-79 in La pratica dello scambio. Sistemi di fiere mercanti e città in Europa (1400-1700), ed. Paola Lanaro. Venice: Marsilio, 2003.

Mozzato, Andrea. L'arte della lana a Venezia nel basso Medioevo: Materia prima, produzione e produttori, doctoral dissertation, Università degli Studi di Milano, 2001-02. Directors: Rinaldo Comba and Patrizia Mainoni.

Musgrave, Peter. 'The Small Towns of Northern Italy in the Seventeenth and Eighteenth Centuries’ pp. 250-270 in Small Towns in Early Modern Europe, eds. Peter Clark. Cambridge, UK: Cambridge University Press, 1995.

Panciera, Walter. L'arte matrice. I lanifici della Repubblica di Venezia nei secoli XVII e XVIII. Treviso: Edizioni Canova, 1996. 
Panciera, Walter. 'La formazione delle specializzazioni economiche territoriali nel Sei e Settecento' pp. 231-346 in L'industria vicentina dal Medioevo a oggi, ed. Giovanni Luigi Fontana. Padua: Cleup, 2004.

Panciera, Walter. 'Qualità e costi di produzione nei lanifici veneti' pp. 419453 in Wool: Products and Markets (13th-20th Century), eds. Giovanni Luigi Fontana and Gérard Gayot. Padua: Cleup, 2004.

Pegrari, Maurizio. Il "continuo giro et moto” dell'economia. Brescia e la "Città nuova” nel Discorso di Vincenzo Botturini (1606). Brescia: Grafo, 2002.

Poni, Carlo. 'Archéologie de la fabrique. La diffusion des moulins à soie “alla bolognese” dans les Etats vénetiens du XVIe a XVIIIe siècle,' Annales ESC, 27 (1972): 1475-96.

Prak, Maarten. 'Regions in Early Modern Europe’ pp. 19-55 in Debates and Controversies in Economic History A-Sessions. Proceedings XI International Economic History Congress. Milan: Università Bocconi, 1994.

Preto, Paolo. I servizi segreti di Venezia. Spionaggio e controspionaggio: cifrari intercettazioni, delazioni, tra mito e realtà. Milan: Il Saggiatore, 1994.

Rapp, Richard. Industry and Economic Decline in Seventeenth-Century Venice. Cambridge MA: Harvard University Press, 1976.

Relazioni dei Rettori Veneti in Terraferma, ed. Istituto di Storia economica dell'università di Trieste: Podestaria e Capitanato di Vicenza, Milan: Giuffré 1976; Podestaria e Capitanato di Verona, Milan: Giuffré, 1977; Podestaria e Capitanato di Bergamo, Milan: Giuffré, 1978.

Sella, Domenico. Commerci e industrie a Venezia nel secolo XVII. Venice and Rome: Istituto per la collaborazione culturale, 1964.

Sella, Domenico. 'The Rise and Fall of the Venetian Woollen Industry' pp. 106-126 in Crisis and Change in the Venetian Economy, ed. Brian Pullan. London: Methuen, 1968.

Sella, Domenico. 'L’economia’ pp. 651-711 in Storia di Venezia, vol. 6: Dal Rinascimento al Barocco, eds. Gaetano Cozzi and Paolo Prodi. Rome: Istituto dell'Enciclopedia Italiana, 1994.

Sella, Domenico. L'Italia del Seicento. Rome and Bari: Laterza, 2000.

Sella, Domenico. 'Industrial Raw Materials in the Import Trade of Northern and Central Italy During the XVIIIth Century” The Journal of European Economic History, 33:1 (2004): 59-70.

Trivellato, Francesca. Fondamenta dei vetrai. Lavoro, tecnologia e mercato a Venezia tra Sei e Settecento. Rome: Donzelli, 2000.

Trivellato, Francesca. 'Tra innovazione e conservazione: le strategie imprenditoriali di Giorgio Barbaria e il sistema locale di produzione di vetro a Venezia nel XVIII secolo' in Sistemi locali e percorsi di industrializzazione, ed. Giovanni Luigi Fontana and Walter Panciera. Padua: Cleup, in press.

Tucci, Ugo. 'Venezia nel Cinquecento: una città industriale'” pp. 61-83 in Crisi e rinnovamenti nell'autunno del Rinascimento a Venezia, ed. Vittore Branca and Carlo Ossola. Florence: Olschki, 1991. 
Van Der Wee, Herman. 'Industrial Dynamics and the Process of Urbanization and De-Urbanization in the Low Countries from the Late Middle Ages to the Eighteenth Century a Synthesis’ pp. 307-381 in The Rise and Decline of Urban Industries in Italy and in the Low Countries, ed. HermanVan der Wee. Leuven: Leuven University Press, 1988 .

Ventura, Angelo. 'Considerazioni sull'agricoltura veneta e sull'accumulazione originaria del capitale nei secoli XVI e XVII.' Studi Storici, 9:3-4 (1968): 674-722.

Ventura, Angelo. 'Introduzione' pp. 165-175 in Dentro lo "Stado Italico". Venezia e la Terraferma fra Quattro e Seicento, Civis Studi e Testi, 8 (1984), n. 24.

Varanini, Gian Maria. Comuni cittadini e stato regionale: Ricerche sulla Terraferma veneta nel Quattrocento. Verona: Libreria Editrice Universitaria, 1992.

Varanini, Gianmaria. 'Le città della Marca trevigiana fra Duecento e Trecento. Economia e società' pp 111-140 in Le città del Mediterraneo all'apogeo dello sviluppo medievale: aspetti economici e sociali, ed. Centro italiano di studi di storia e d'arte. Pistoia: presso la sede del Centro, 2003.

Vianello, Andrea. L'arte dei calegheri e zavateri di Venezia tra XVII e XVIII secolo. Venice: Istituto Veneto di Scienze, Lettere e Arti, 1993.

Vianello, Francesco. Seta fine e panni grossi. Manifatture e commerci nel Vicentino 1570-1700. Milan: Franco Angeli, 2004.

Vianello, Francesco. 'Mercanti, imprese e commerci nel Cinque e Seicento' pp. 187-229 in L'industria vicentina dal medioevo a oggi, ed. Giovanni Luigi Fontana. Padua: Cleup, 2004.

Wallerstein, Emanuel, The Modern World-System, vol. 1: Capitalistic Agriculture and the Origins of the European World-Economy in the Sixteenth century. New York: Academic Press Inc., 1974; vol. 2: The Modern World-System. Mercantilism and the Consolidation of the European World-Economy, 1600-1750. New York and London: Academic Press 1980.

Zalin, Giovanni. Dalla bottega alla fabbrica: La fenomenologia industriale nelle province venete tra '500 e '900. Verona: Libreria Universitaria Editrice, 1987. 